PONTIFÍCIA UNIVERSIDADE CATÓLICA DO RIO DE JANEIRO

\title{
Percepção e atitude do consumidor sobre o atendimento na Disney
}

\author{
Letícia Reis Silva
}

Trabalho de Conclusão de CuRso

Centro de CiênCIAS SOCIAIS - CCS

DePARTAMENTO dE AdMINISTRAÇÃO

Graduação em Administração de Empresas 

หั

Letícia Reis Silva

\section{Percepção e atitude do consumidor sobre o atendimento na Disney.}

Trabalho de Conclusão de Curso

Trabalho de Conclusão de Curso, apresentado ao programa de graduação em Administração da PUC-Rio como requisito parcial para a obtenção do titulo de graduação em Administração.

Orientador(a) : Marcus Hemais

Rio de Janeiro

Novembro de 2019. 


\section{Agradecimentos}

Aos meus pais, irmã e toda minha família que me apoiaram durante essa longa jornada com muito amor e incentivo para alcançar os meus objetivos. Ao meus grandes amigos do Garriga, de Macaé, da PUC e da vida, um grande obrigada por tornarem essa caminha mais divertida e por sempre acreditarem em mim. Aos excelentes professores que contribuíram com minha formação e crescimento pessoal e profissional, com especial agradecimento ao meu orientador Marcus Hemais. 


\section{Resumo}

Silva, Letícia Reis. Percepção e atitude do consumidor sobre o atendimento na Disney. Rio de Janeiro, 2019. Número de páginas 54. Trabalho de Conclusão de Curso - Departamento de Administração. Pontifícia Universidade Católica do Rio de Janeiro.

Este estudo teve como objetivo analisar a percepção e a atitude de consumidores em relação ao atendimento do funcionário oferecido pela Disney a seus convidados. Assim, são analisados temas referente ao comportamento do consumidor e ao marketing de serviços. Para tal, foi realizada uma pesquisa qualitativa através de entrevistas em profundidade com consumidores brasileiros que tenham visitado os parques temáticos da Walt Disney World pelo menos duas vezes nos últimos cinco anos.

Palavras- chave

Comportamento do consumidor, percepção, atitude, papel do funcionário, Walt Disney World. 


\section{Abstract}

Silva, Letícia Reis. Perception and attitude of the consumer about Disney's service. Rio de Janeiro, 2019.Number of pages 54. Course Completion Work Business Administration Department. Pontifical Catholic University of Rio de Janeiro.

This study aims to analyze the perception and attitude of consumers regarding the employee service offered by Disney to its guests. Thus, themes related to consumers behavior and service marketing are analyzed. To this end, a qualitative research was conducted through in-depth interviews with Brazilian consumers who have visited Walt Disney World theme parks at least twice in the last five years.

Keywords: Consumer behavior, perception, attitude, employee role, Walt Disney World. 


\section{Sumário}

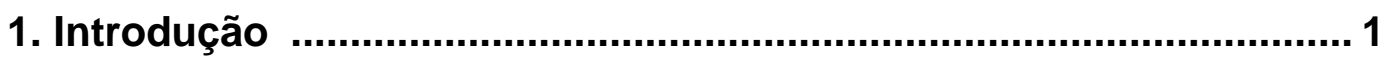

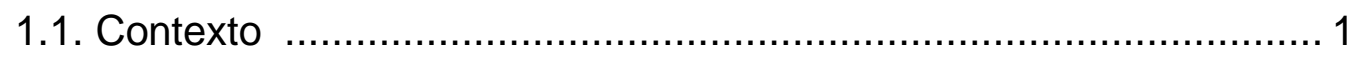

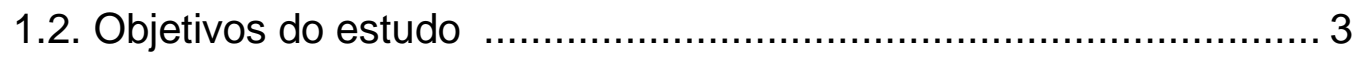

1.3. Delimitação e foco do estudo ................................................... 3

1.4. Justificativa e relevância do estudo ............................................. 4

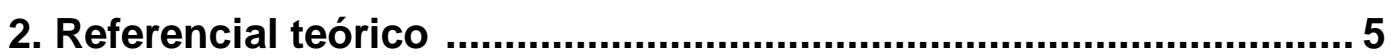

2.1. Percepção do consumidor ..................................................... 5

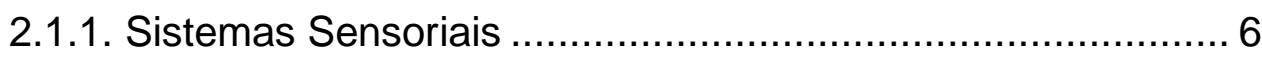

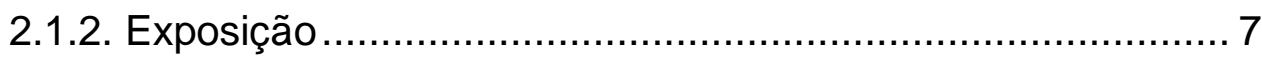

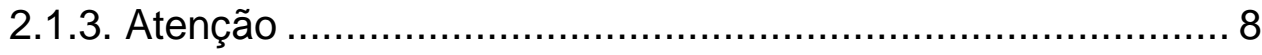

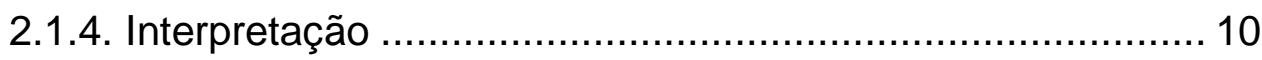

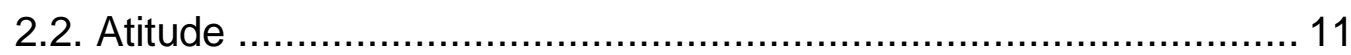

2.3. Papel do funcionário na prestação de serviços ………………... 12

3. Metodologia do estudo ……............................................................ 16

3.1. Tipo de pesquisa realizado ................................................... 16

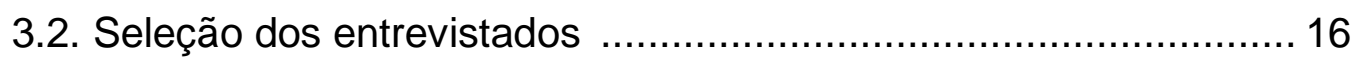

3.3. Procedimento de coleta dos dados .......................................... 17

3.4. Processamento de análise dos dados ........................................ 18

3.5. Limitações da metodologia ....................................................... 18

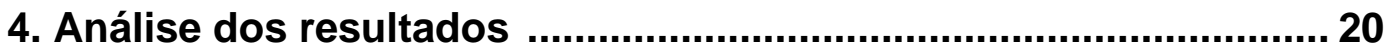

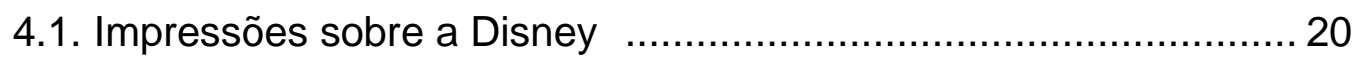

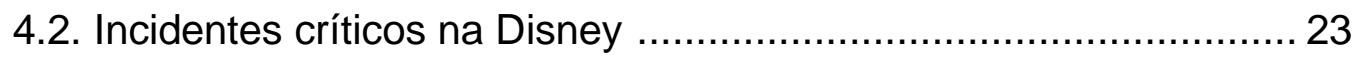

4.3. Relatos dos acompanhantes dos entrevistados durante $\mathrm{o}$ incidente .

4.4. Opiniões após o incidente crítico …………………………..... 28

5. Conclusões e recomendações para novos estudos .......................31 


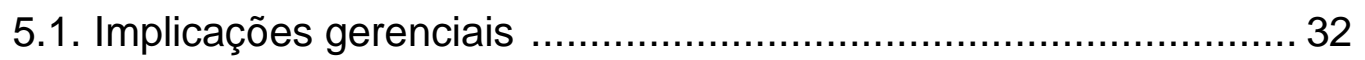

5.2. Sugestões de futuros estudos ............................................... 32

6. Referências Bibliográficas .......................................................... 34

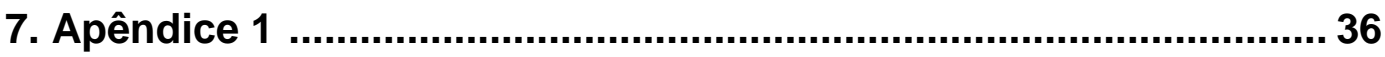

8. Apêndice 2

\section{Lista de Figuras}

Figura 1 - Mapa Walt Disney World ................................................................

Figura 2 - Visão geral do processo perceptivo ............................................. 6

Figura 3 - Triângulo dos serviços ...............................................................13

Figura 4 - As estratégias de contratação de pessoas que prestarão serviço

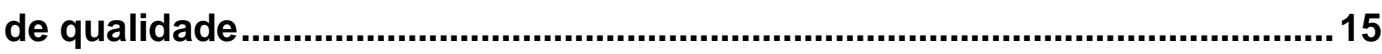

\section{Lista de Tabelas}




\section{Introdução}

\subsection{Contexto}

A Walt Disney Company é uma multinacional de mídia e entretenimento conhecida ao redor do mundo. A empresa possui cinco principais divisões: a unidade Media Networks, responsável pelos canais, rádios e produtos relacionados - como ABC, ESPN, Disney Channel e FOX -; a Studio Entertainment, que engloba tudo relacionado a cinema, teatro e música, sendo composta pela Walt Disney Pictures, Marvel Studios, Lucasfilm, Pixar, Disney Nature, Disney on Ice, Hollywood Records, Disney Theatrical Group, entre outros; a Direct-To-Consumer and International, composta por serviços digitais como Disney+, ESPN+, Hulu e Hotstar; e, por último, a unidade Parks, Experiences and Products, responsável por tornar reais as histórias e os personagens através dos parques, resorts, cruzeiros e produtos, como jogos, livros e brinquedos (WALT DISNEY WORLD, 2019). Segundo relatório anual realizado pela Interbrand (2018), a Disney está em 14ํㅡo ranking de 2018 das empresas mais valiosas do mundo, com um valor estimado de 39,874 milhões de dólares.

O complexo de Parques e Resorts é responsável por $34.2 \%$ da receita total da Walt Disney Company, ficando apenas atrás da unidade de Mídia com $41.2 \%$, mostrando sua importância para a empresa, segundo o balanço de receitas de 2018 retirado do Relatório Financeiro Anual 2018 (WALT DISNEY COMPANY, 2018, p.32). Além disso, a unidade está em primeiro lugar dos melhores parques temáticos do mundo, trazendo 150 milhões de visitantes em 2017 (AECOM, 2017), sendo 37,3\% concentrados nos parques da Flórida que compõem o Walt Disney World (WDW), sendo eles Magic Kingdom, Animal Kingdom, Epcot e Hollywood Studios, que, juntos, possuem 164 atrações e $40 \mathrm{~km}^{2}$ para atrair todos os seus visitantes (WDW NEWS, 2014). A figura 1, a seguir, representa o mapa com os parques que fazem parte do complexo Walt Disney World. 
Figura 1: Mapa Walt Disney World

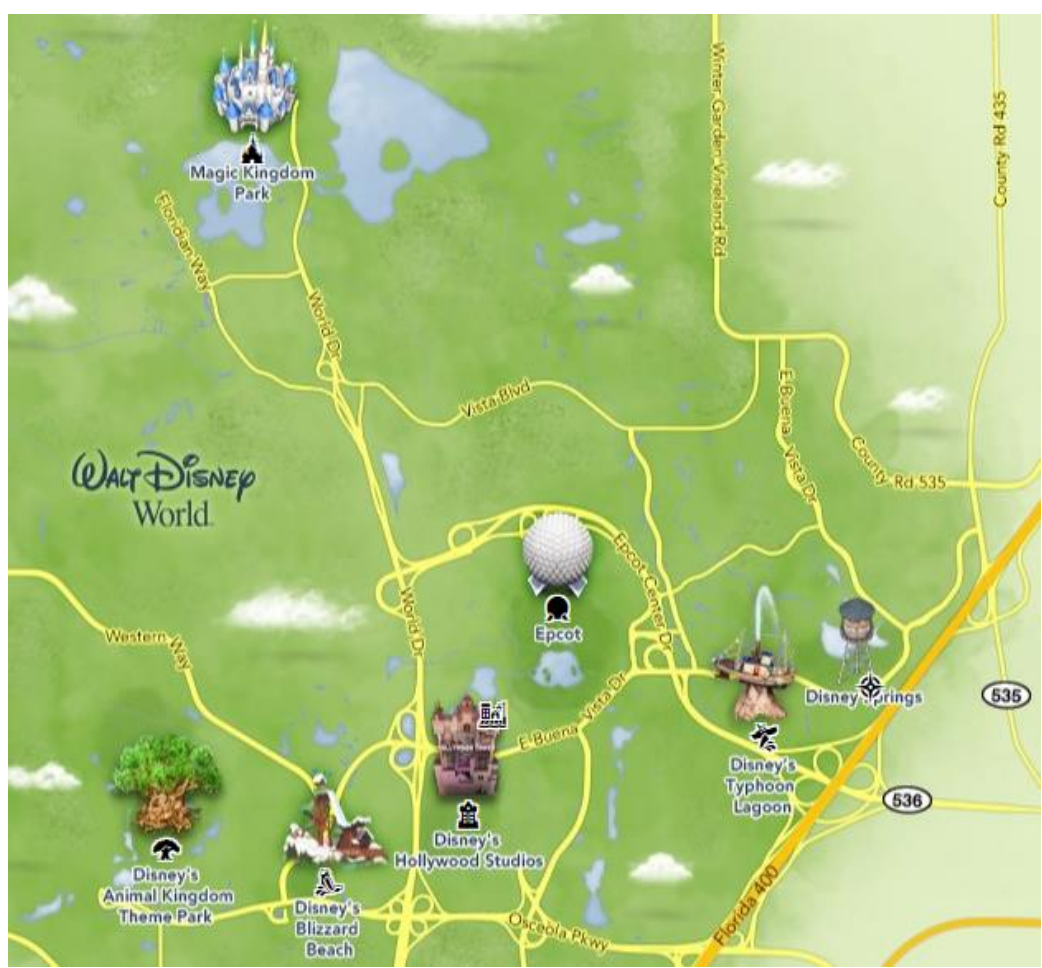

Fonte: WDW

A WDW consegue um índice de fidelização de $70 \%$ de seus clientes (DISNEY INSTITUTE, 2011), praticando o que seu slogan diz: "Onde seus sonhos se realizam". Os parques conseguem oferecer uma experiência completa para todos os seus visitantes, que são chamados de "guests" (em português, convidados, no sentido de estarem realizando um show para as pessoas), através de atrações, restaurantes e, principalmente, um excelente atendimento. A Disney possui mais de 70.000 mil "cast members" (em português, elenco) para servir com arte todos os seus convidados, sendo uma das maiores empregadoras dos Estados Unidos (WDW NEWS, 2014). Cada um deles contribui para oferecer a melhor experiência para os clientes, os chamados "magical moments", isto é, momentos mágicos que o elenco faz fora do padrão para deixar o dia de algum convidado mais feliz, podendo ser um adesivo do Mickey, um sorvete caso o seu tenha caído no chão, presentear você com um pin ou um convite para participar de alguma parada ou show. Dessa forma, buscam aumentar a lealdade dos convidados e os seus desejos de voltar.

Do ponto de vista financeiro, como é abordado por Zeithaml e Bitner (2003), o marketing com foco em serviços visa atrair mais e melhores clientes, cujas intenções de se comportarem de maneira positiva, são afetadas pela 
satisfação e percepção da qualidade de serviço. Com isso, os funcionários possuem um papel importante de oferecerem um serviço de excelência para os clientes, gerando consequências positivas à empresa, na forma, especialmente, de fidelidade do consumidor. Para o cliente, a magia é uma fonte de encantamento e prazer. Para a empresa e os seus funcionários, é uma questão prática (DISNEY INSTITUTE, 2011). Diante deste cenário, torna-se importante responder a seguinte pergunta: como é a percepção e a atitude do consumidor sobre o atendimento na Disney?

\subsection{Objetivos do estudo}

O presente trabalho tem o objetivo de analisar a percepção e a atitude de consumidores em relação ao atendimento oferecido por funcionários da Disney a seus convidados. Através desta pesquisa, espera-se entender melhor como um serviço de qualidade influencia na avaliação do consumidor.

\subsection{Delimitação e foco do estudo}

Esta pesquisa volta-se especificamente para abordar algumas vertentes relacionadas a comportamento do consumidor e marketing de serviços. Os aspectos sobre comportamento do consumidor estudados serão a atitude e a percepção do consumidor. Será analisado também um tema relacionado a marketing de serviços, que é o papel do funcionário para compreender o atendimento deste e como influencia no comportamento dos clientes.

Além disso, a pesquisa só irá focar na perspectiva do consumidor, não considerando a visão dos funcionários, nem da própria empresa Disney.

Este trabalho terá como foco consumidores brasileiros que foram aos parques temáticos da Walt Disney World pelo menos duas vezes nos últimos cinco anos. Entretanto, serão considerados apenas os quatro parques principais: Magic Kingdom, Epcot, Hollywood Studios e Animal Kingdom, sendo excluídos os parques aquáticos, os resorts e a área de Downtown Disney.

\subsection{Justificativa e relevância do estudo}


As informações levantadas por esse estudo podem ser relevantes para o mundo empresarial, principalmente para servir de benchmarking a empresas de diversos setores, de forma que possam compreender o impacto da satisfação do cliente na avaliação da qualidade de serviço ou empresas que utilizarão o atendimento ao cliente como base em busca de aumentar fidelização destes. Podem, ainda, ser de interesse para a própria Disney e agências de viagem que buscam colher informações sobre as opiniões de consumidores brasileiros quanto à sua experiência nos parques. 


\section{Referencial teórico}

O presente item discute o referencial teórico e aborda três tópicos. Os dois primeiros aspectos conceituais estão relacionados ao comportamento do consumidor, mais especificamente os conceitos de percepção e atitudes. O terceiro discute sobre o papel do funcionário, um conceito do estudo de marketing de serviços.

\subsection{Percepção do consumidor}

Segundo Solomon (2016), a percepção consiste no processo pelo qual o consumidor seleciona, organiza e depois interpreta as sensações, que são resposta imediata dos receptores sensoriais (olhos, ouvidos, nariz, boca, dedos, pele) a estímulos básicos como luz, cor, som, odores e texturas. Desse modo, o foco do estudo da percepção é concentrar-se no que se pode acrescentar a essas sensações, a fim de Ihe dar um significado. Percepção é, portanto, o ato psicológico que possui peso no momento exato da compra (KOTLER; KELLER, 2011)

Para Hoyer e Maclnnis (2011), os consumidores tendem a não perceber um estímulo se este estiver isolado; o que irão fazer é organizar e assimilar no contexto de outras coisas que estão ao redor de tal estímulo. Essa organização perceptual ocorre no momento que os consumidores organizam um conjunto de estímulos em um todo de forma coerente, sendo afetado pelos princípios de figura e fundo, encerramento, agrupamento e viés pelo todo. O primeiro princípio consiste no fato de que as pessoas interpretam mais facilmente estímulos que estão como figuras destacadas em primeiro plano, enquanto o fundo não está em destaque, ficando em segundo plano. O encerramento diz respeito à tendência dos consumidores em completar estímulos que estejam incompletos. O agrupamento é o fato dos consumidores terem a necessidade de agrupar objetos que estejam próximos ou que sejam semelhantes, a fim de ter uma interpretação unificada. Por último, o viés pelo todo consiste na premissa de que existe mais valor na soma das partes do que nas partes separadas.

Nosso cérebro recebe constantemente estímulos externos que podem tornar-se experiências sensoriais internas. Assim, torna-se determinante para o 
sucesso de vendas de um produto ou serviço as suas características sensoriais, visto que essa experiência do consumidor ajuda a destacar o bem daquele oferecido pela concorrência, aumentando, assim, a sua vantagem competitiva. A tendência dos consumidores é cada vez mais querer comprar aquilo que apresenta não só um valor funcional, mas também um valor multissensorial.

Para melhor entendimento do processo perceptivo, iremos analisar sua visão geral, representada na Figura 2, a seguir. Primeiro, serão discutidos os sistemas sensoriais e, em seguida, analisam-se os três estágios de exposição, atenção e interpretação.

Figura 2: Visão geral processo perceptivo

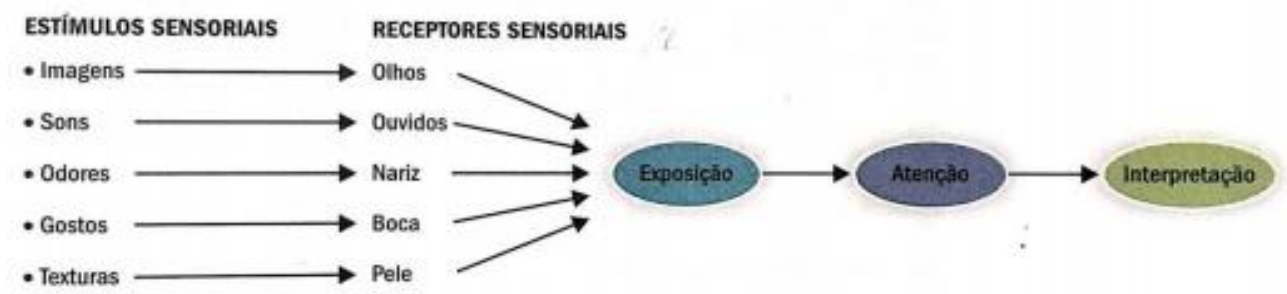

Fonte: Solomon (2016)

\subsubsection{Sistemas Sensoriais}

As sensações experimentadas são efeitos do contexto que influencia sutilmente um pensamento sobre um produto ou serviço (SOLOMON, 2016). Essas associações podem ser feitas através de nossos cinco sentidos: visão, olfato, audição, tato e paladar.

De acordo com Solomon (2016), elementos visuais transmitem significado por meio da cor, tamanho e estilo do produto. As cores influenciam nossas emoções de maneira mais direta; existem evidências de que algumas cores transmitem uma maior calma ou excitação. As reações desses estímulos visuais provêm de associações aprendidas ou de diferenças biológicas e culturais.

Quanto aos aromas, algumas reações despertam sensações boas ou ruins. Para Ellen e Bone (1998), as empresas exploram as associações entre aromas, memórias e estados de espírito, porque provêm de antigas associações. Por exemplo, segundo uma pesquisa da Folgers (2010), muitas pessoas associam o cheiro de café com recordações da infância. Processamos sugestões de odores em nosso sistema límbico, a parte do cérebro em que são vivenciadas as emoções imediatas (SOLOMON, 2016). 
As sensações na pele, sejam de uma relaxante massagem ou de um vento cortante, nos estimulam. Um estudo mostra que clientes que são gentilmente tocados pelos funcionários tendem a oferecer gorjetas maiores (HORNIK, 1992). Para Solomon (2016), as sensações hápticas moderam a relação entre a experiência com o produto e a confiança no julgamento.

Para Krishna (2010), as características sensoriais podem acentuar atitudes, percepções e a satisfação dos consumidores. Um exemplo são as músicas e outros sons que afetam os sentimentos e comportamento das pessoas. Os consumidores são mais propensos a reconhecer nomes de marca que começam com uma consoante tônica, como P da marca Pepsi (SOLOMON, 2016).

Por último, têm-se o paladar, que contribui para a experiência do consumidor. De acordo com Allen e Monnier (2008), a imagem de um alimento e o valor que atribuímos para ele influenciam na nossa experiência com o sabor real.

Para Solomon (2016), nem sempre as sensações são completamente notadas, isto porque são pequenos estímulos. Além disso, esse mesmo estímulo pode ser interpretado de maneiras diversas entre as pessoas, que irão interpretar de acordo com suas próprias memórias, associações, concepções e necessidades.

\subsubsection{Exposição}

O início do processo perceptivo ocorre no estágio da exposição, quando um estímulo sensorial penetra nos receptores sensoriais do indivíduo, por exemplo, quando um apito é usado e o som chega ao seu ouvido (SOLOMON, 2016).

Hoyer e Maclnnis (2011, p. 62) descrevem o estágio da exposição da seguinte maneira:

Exposição é o processo pelo qual o consumidor entra em contato com um estímulo, que são mensagens e informações sobre ofertas. É essencial para influenciar os pensamentos e sentimentos dos consumidores, desde que sejam expostos aos estímulos em um ângulo favorável. 
Segundo Solomon (2016), algumas pessoas conseguem captar melhor as informações sensoriais do que aquelas cujos canais podem estar prejudicados, e, assim, estímulos recebidos por elas estarão abaixo do limiar sensorial desse indivíduo, isto é, não irá provocar um impacto sobre a consciência da pessoa. De acordo com Hoyer e Maclniss (2011), os consumidores controlam se sua exposição a estímulos ocorre ou não, podendo buscar ativamente estímulos ou até mesmo evitá-los, como, por exemplo, usuários que baixam softwares para evitarem "pop-up".

As empresas devem estar atentas a esse limiar, uma vez que estes determinam até onde o indivíduo é capaz de captar estímulos externos. De acordo com Solomon (2016, p.184), este limiar se divide entre o absoluto e o diferencial. O primeiro se refere à "quantidade mínima de um estímulo que uma pessoa consegue captar em determinado canal sensorial", por exemplo, quando um outdoor possui um texto divertido, mas as letras são pequenas e os motoristas não conseguem enxergar. O segundo consiste na "capacidade de um sistema sensorial de detectar mudanças ou diferenças entre os estímulos", relevante para situações de marketing, como quando um varejista está oferecendo um desconto e deseja que seus clientes percebam a diferença no valor. De acordo com a Lei de Weber, para que essa diferença seja percebida, é necessário aumentar a intensidade do estímulo.

A percepção subliminar consiste na ativação dos receptores sensoriais dos indivíduos através de estímulos que são apresentados de maneira tão rápida que ficam abaixo do limiar da percepção (HOYER; MACLNISS, 2011).

Solomon (2016) ressalta a importância de saber que mesmo que o efeito seja alcançado, o estímulo irá afetar o impulso básico, e não a demanda sobre um produto específico. Por exemplo, uma mensagem pode aumentar a fome do indivíduo, mas não sua necessidade de comprar um doce de uma marca específica.

\subsubsection{Atenção}

A próxima fase do processo é a atenção, que, segundo Solomon (2016), consiste no grau de dedicação da atividade de processamento é dirigido a um estímulo específico, o que varia de acordo com as características desse estímulo e de seu receptor. 
Para Hoyer e Mclannis (2011), a atenção possui três importantes características: é seletiva, pode ser dividida e é limitada. A seletividade consiste no fato de que os consumidores podem decidir no que eles desejam se concentrar, selecionando e escolhendo entre os estímulos, evitando serem sobrecarregados. De acordo com Solomon (2016), essa seleção tem influência de fatores pessoais e do próprio estímulo. O primeiro considera a vigilância perceptiva, isto é, tendência dos consumidores de ficarem mais atentos a estímulos relacionados com suas necessidades atuais, a defesa perceptiva, quando um estímulo ameaça um indivíduo e ele não o processa ou distorce seu significado, e a adaptação, intensidade a qual os consumidores continuam a receber um estímulo após determinado tempo sendo influenciado por sua intensidade, discriminação, exposição e relevância. O segundo refere-se às características de contraste do estímulo quanto ao seu tamanho, cor, posição e novidade.

Outro aspecto da atenção é que ela pode ser dividida, isto é, os indivíduos têm a capacidade de alocar os recursos de atenção para mais de uma tarefa (HOYER E MACLNISS, 2011). Solomon (2016) chama essa atividade de multitarefa, que ocorre, por exemplo, quando indivíduos estão assistindo um filme na TV enquanto respondem uma mensagem no celular. O impacto dessa atividade sobre o consumidor é a ânsia por altas cargas de informação que, consequentemente, os deixa entediados caso não recebam, diminuição da capacidade de concentração e aumento do estresse.

O terceiro aspecto consiste no fato de ser limitada. Por mais que possa ser dividida, quando o processo demandar esforço e não for uma atividade relativamente automática, será necessário cortar esse estímulo (HOYER; MACLNISS, 2011). Para Solomon (2016), o processo de seleção perceptiva significa que as pessoas atendem somente a uma pequena parcela de estímulos a que são expostas.

A informação tem mais impacto quando os consumidores dedicam mais atenção, isto é, o processamento pré-atencional, e para aumentar essa dedicação é necessário tornar o estímulo mais relevante pessoalmente, mais agradável, mais surpreendente e fácil de processar. Para aumentar sua relevância, pode-se apelar para as necessidades, valores, emoções e objetivos dos consumidores, utilizar de dramatizações e de perguntas teóricas. Os estímulos podem ser mais agradáveis se forem mais atraentes, com música e humor, por exemplo. Um estímulo é mais surpreendente por causa de sua novidade, imprevisibilidade e/ou natureza desconcertante. Por último, para tornar 
um estímulo mais fácil de processar é necessário que este possua quatro características: ser proeminente, material, em contraste com o seu redor e pela quantidade de informações que tem como concorrente (HOYER E MCLANNIS, 2011).

\subsubsection{Interpretação}

O terceiro e último estágio consiste naquele que os consumidores irão atribuir significado aos estímulos sensoriais recebidos que irão variar para cada indivíduo. Essa diferença de interpretação se dá pelo conjunto de crenças do receptor, suas sensações, memória e suposta relação com outros eventos (SOLOMON, 2016).

Para Solomon (2016), os consumidores tendem a relacionar sensações novas com outras já armazenadas na memória, baseados nos princípios da psicologia Gestalt, que defende a perspectiva parcial, isto é, que considera cada parte do estímulo analisada separadamente, sendo incapaz de captar o efeito total. De acordo com essa perspectiva, os estímulos são organizados de três maneiras: complementação, similaridade e figura-fundo. O primeiro consiste na tendência dos indivíduos de preencherem vazios baseando-se em experiências prévias; o segundo diz respeito ao fato de as pessoas tenderem a agrupar objetos que compartilham características semelhantes; e o último é a constatação de uma parte do estímulo estar mais evidente que outras, que ficam em segundo plano.

A avaliação e a percepção dos consumidores sobre produtos decorre da compreensão sobre os atributos físicos, como preço, e simbólicos, como a imagem e o que representa. De acordo com Solomon (2016), existe um elo, chamado de semiótica, que examina essa relação entre signos e símbolos e a função desses na atribuição de significados, podendo ser por semelhança, associação ou vinculação. Quando uma empresa compreende como os consumidores fazem esse processo, podem utilizar dessa percepção para desenvolver estratégia de posicionamento da marca, como por estilo de vida, liderança de preço, por atributo, classe de produto, concorrentes, ocasiões, usuários ou por qualidade. 


\subsection{Atitude}

A atitude é um tema de estudo importante para o marketing, uma vez que está relacionada ao comportamento do consumidor e se esse indivíduo responderá de forma favorável ou desfavorável a algum estímulo. De acordo com Solomon (2016), a atitude é uma avaliação genérica que têm a tendência de persistir no tempo sobre algo. Atualmente, recebemos informações de uma grande quantidade de fontes e em uma frequência cada vez mais alta, o que faz com que nosso esforço para tomar uma atitude seja maior. O pesquisador Daniel Katz desenvolveu uma teoria que consiste nas principais funções da atitude: utilitária, expressiva de valor, ego-defensiva e do conhecimento. A primeira está relacionada com a relação recompensa e punição, a segunda diz respeito a crenças e valores do consumidor, a terceira forma uma barreira contra ameaças, e a última consiste na ordenação em situações novas.

Para Rocha, Ferreira e Silva (2012), a atitude é composta por três componentes: cognição, afetiva e comportamental, mostrando uma relação entre o conhecer, o sentir e o fazer. A primeira diz respeito a como as opiniões podem afetar o pensamento das pessoas, isto é, ela incorpora as expectativas do consumidor e suas crenças com relação a algum bem. A segunda mostra como afeta os sentimentos e as emoções, principalmente quando a relação é com produtos hedônicos, que ocorre, por exemplo, quando os consumidores preferirem produtos nacionais ao invés daqueles importados. Por último, têm-se o comportamento que diz respeito à disposição do consumidor em tomar uma atitude. Segundo Solomon (2016), cada um desses elementos pode iniciar um processo de atitude que terá como resultado três hierarquias diferentes: a de aprendizagem padrão (solução de problema baseada em informações cognitivas), a de baixo envolvimento (atitude baseada em conhecimentos) e a experiencial (formada inicialmente em uma reação emocional primária).

O grau de comprometimento de uma atitude pode variar para cada consumidor, estando relacionado com sua lealdade e nível de envolvimento com a marca. De acordo com Solomon (2016), existem três níveis de comprometimento, o primeiro é o da condescendência, o nível mais baixo, que apresenta um menor envolvimento entre objeto e consumidor, resultando em uma atitude mais superficial. Depois, a identificação, processo no qual é formada uma atitude que se assemelhe a de outra pessoa, buscando uma adequação ao grupo. Por último, a internalização, que representa o nível mais alto de 
envolvimento com atitudes mais enraizadas e difíceis de mudar, chegando a fazer parte de uma identificação social do consumidor.

De acordo Solomon (2016), o princípio da coerência consiste no conceito de que as atitudes devem ser condizentes com outras atitudes já tomadas e caso haja alguma incoerência entre atitudes e comportamentos, os consumidores tendem a mudar, eliminar ou incluir algum elemento para resolver essa dissonância cognitiva. Um exemplo é quando o consumidor é fumante, mas sabe que o tabaco irá lhe causar câncer e uma forma dele reduzir essa incoerência e dissonância é incluir um elemento como o fato de sua tia ter fumado a vida inteira e mesmo assim nunca ter tido câncer.

Existem modelos de atitude que possuem como objetivo identificar componentes de uma atitude para conseguir prever uma próxima atitude do consumidor com relação a algo. Para Schiffman e Kanuk (2000), a avaliação sobre a estruturação de uma atitude têm importância quanto ao entendimento do papel das atitudes no comportamento do consumidor. O modelo de atitude multiatributo busca entender a complexidade das atitudes estudando a relação entre a atitude e as crenças do consumidor sobre os atributos do objeto, para que, assim, possa fazer uma associação e compreender uma atitude global do consumidor. O multiatributo pode servir para aproveitar a vantagem relativa, fortalecer os vínculos entre produto e atributo, acrescentar um novo atributo e influenciar as classificações dos concorrentes, entretanto mesmo com esse conhecimento nem sempre é possível prever as atitudes dos consumidores (SOLOMON, 2016).

\subsection{Papel do funcionário na prestação de serviços}

Os funcionários possuem um papel fundamental e estratégico para uma empresa, uma vez que garantem a eficiência dos processos e são responsáveis por gerar a satisfação do cliente. De acordo com Berry (1999), um dos principais fatores para o sucesso de uma empresa consiste na valorização e investimento nos funcionários, tornando-se uma vantagem competitiva e estimulante para fidelidade dos clientes.

As crenças e os valores praticados pela empresa exercem influência sobre o comportamento dos funcionários, tanto individual, quanto coletivamente. As empresas voltadas para o serviço e com foco na satisfação do cliente tendem a ter uma cultura de serviços que valoriza o atendimento de qualidade, que 
ocorre naturalmente e é considerado uma vantagem competitiva. Zeithaml, Bitner e Germler (2014, p. 310), definem a cultura corporativa da seguinte forma:

Cultura corporativa é o padrão comum de valores e crenças que gera uma noção de finalidade aos integrantes de uma empresa e que lhes fornece as regras de comportamento dentro dela.

Os funcionários exercem papel essencial na prestação de serviços por que são vistos como os representantes do serviço, estando em constante contato direto com os clientes. Eles também personificam a empresa aos olhos do cliente, ou seja, qualquer comportamento do funcionário serve como uma reflexão sobre a organização (ZEITHAML, BITNER E GERMLER, 2014). Além disso, pelo fato da linha de frente ser o elemento mais visível do serviço, os funcionários são parte essencial da marca, responsáveis por cumprir a sua promessa (LOVELOCK; WIRTZ, 2006).

De acordo com Zeithaml, Bitner e Gremler (2014), existem três grupos que são de extrema importância para que a empresa possa cumprir suas promessas: a companhia, os funcionários e os clientes. A interação entre os grupos resulta em três tipos diferentes de marketing: o marketing externo que faz a promessa, o marketing interno que possibilita o cumprimento dessa promessa e o marketing interativo que cumpre a promessa, como é ilustrado na figura a seguir.

Figura 3: Triângulo dos serviços

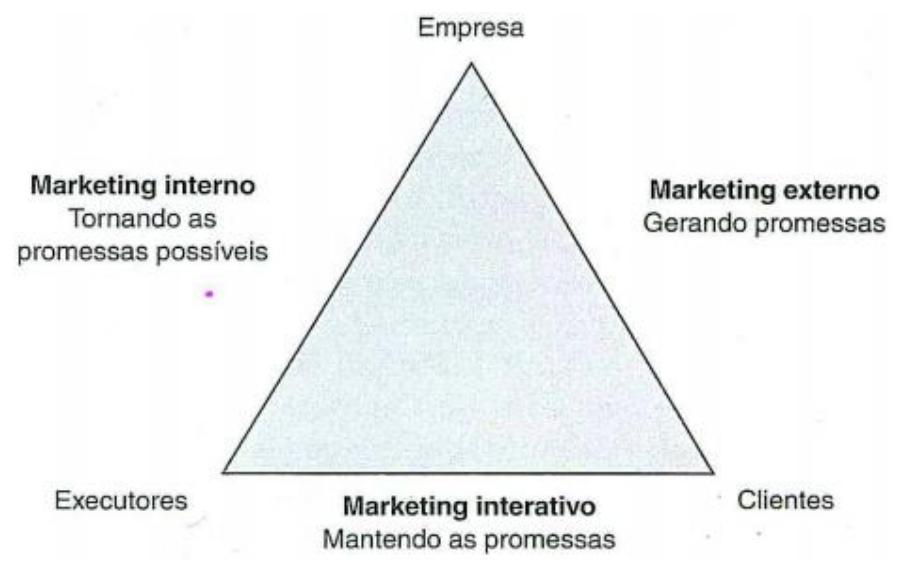

Fonte: Zeithaml, Bitner e Germler (2014, p. 315)

Para Schneider e Bowen (1993), os consumidores tendem a ter percepções positivas do serviço em empresas que o clima do serviço e o bem- 
estar do funcionário são agradáveis, isto é, as atitudes dos funcionários estão correlacionadas com a forma que a empresa os trata. Por sua vez, o comportamento dos funcionários de contato influencia nas principais dimensões de qualidade de um serviço: confiabilidade, responsividade, segurança, empatia e tangíveis. Os empregados são responsáveis por garantir o funcionamento dos equipamentos e processos, atender com prontidão e auxiliar da melhor maneira possível, transpassar credibilidade, prestar atenção e compreender as necessidades dos clientes e estarem com vestimentas adequadas ao ambiente.

Os funcionários da linha de frente, também chamados de solucionadores de problemas, devem medir o estresse que têm para que não falhem em suas atividades. Para Zeithaml, Bitner e Germler (2014), os empregados devem ter inteligência emocional e ter emoções consonantes com as desejadas pelas organizações, sendo cordiais, gentis e empáticos. Além disso, é importante que os funcionários sejam capazes de lidar com conflitos pessoais e interorganizacionais (regra organização vs. satisfação cliente; papel desempenhado vs. crença pessoal; cliente $x$ cliente) e buscar equilibrar os tradeoffs entre qualidade e produtividade, sem falharem em suas tarefas, ficarem estressados ou insatisfeitos. De acordo com Lovelock e Wirtz (2006), outras dificuldades da linha de frente consiste na multiplicidade papéis, agilidade e eficiência, vendas cruzadas, fazer programação de preços e capacidade de ligar o interior da organização com o mundo externo.

Para Zeithaml, Bitner e Germler (2014), a garantia de um serviço de qualidade consiste em estratégias voltadas para permitir que os funcionários atendem com eficácia, eficiência e produtividade, como é ilustrado na figura 4. Primeiramente, deve-se estar atento aos processos de recrutamento e seleção, avaliando as habilidades técnicas e a orientação das pessoas quanto a clientes e serviços, buscando atrair os melhores talentos. Para Lovelock e Wirtz (2006) é importante nunca parar de treinar os funcionários e fortalecer a linha de frente para que estejam preparados, com habilidades técnicas e interpessoais, para tomar decisões e trabalhar em equipe. De acordo com Zeithaml, Bitner e Germler (2014), para trabalhar de forma eficiente e eficaz, o funcionário deve contar com sistemas de apoio internos focados no valor e satisfação do cliente, como acesso a tecnologia, que mensure a percepção do cliente quanto à qualidade. Por último, deve-se preocupar em reter os talentos, deixando a visão da empresa clara e motivadora, valorizando as necessidades dos clientes e premiando a excelência no serviço. 
Figura 4: As estratégias de contratação de pessoas que prestarão serviço de qualidade.

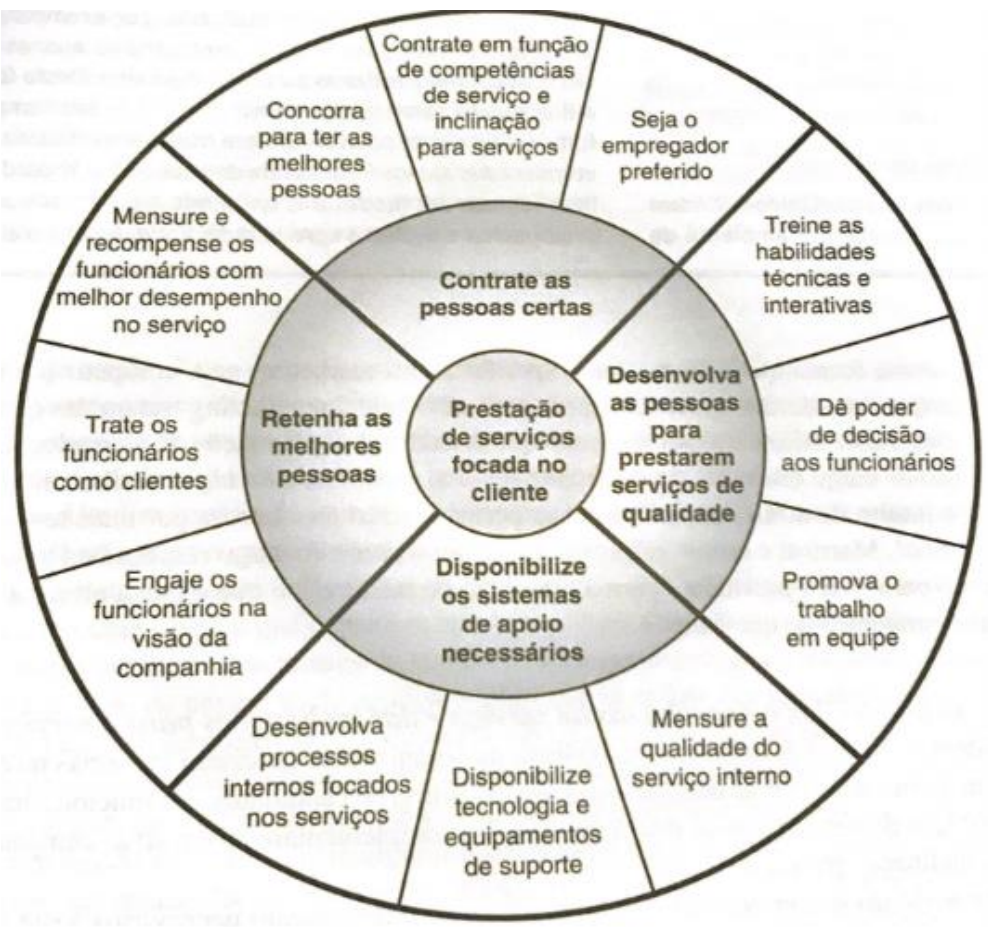

Fonte: Zeithaml, Bitner e Germler (2014, p. 323) 


\section{Metodologia do estudo}

O presente capítulo discute os procedimentos metodológicos adotados no presente estudo. Está dividido em cinco tópicos que informam, respectivamente, o tipo de pesquisa realizada, a seleção dos entrevistados, o procedimento de coleta de dados, o processamento de análise dos dados e, por fim, as limitações das metodologias.

\subsection{Tipo de pesquisa realizado}

A presente pesquisa é classificada como exploratória, uma vez que permite um maior conhecimento e compreensão sobre a situação estudada. A pesquisa de cunho exploratório pode proporcionar uma maior familiaridade com o tema de interesse, de maneira a torná-lo mais explícito para que, então, o pesquisador possa construir hipóteses (GIL, 2008).

Além de exploratória, a metodologia também é de natureza qualitativa, se preocupando com um aprofundamento mais teórico ao invés do numérico. Dentre as vantagens desse tipo de pesquisa, Gil (2008) destaca a possibilidade de considerar a subjetividade dos indivíduos. É uma técnica eficiente visto que possibilita obtenção de dados com maior profundidade. Além disso, oferece uma maior flexibilidade por não exigir que as pessoas saibam ler ou escrever e, também, porque permite que o entrevistador explique e adapte as perguntas para cada circunstância.

\subsection{Seleção dos entrevistados}

A seleção dos entrevistados teve como critério atingir pessoas que tivessem visitado aos parques da Walt Disney World, pelo menos duas vezes nos últimos cinco anos. A escolha dos participantes se deu por conveniência e o seu contato foi feito por meio de indicações de pessoas conhecidas da pesquisadora ou em redes sociais.

Ao todo, foram entrevistadas 17 pessoas com diferentes perfis mas que já tivessem visitado os parques temáticos da Walt Disney World pelo menos duas 
vezes nos últimos cinco anos. A seguir, na Tabela 1, são apresentadas as características de cada entrevistado:

Tabela 1: Perfil dos Entrevistados

\begin{tabular}{|c|c|l|l|l|}
\hline Entrevistado & Idade & \multicolumn{1}{|c|}{ Ocupação } & Estado Civil & \multicolumn{1}{|c|}{ Quando foi para Disney } \\
\hline 1 & 21 & Estudante & Solteiro (a) & $2014,2015,2016,2019$ \\
\hline 2 & 20 & Estudante & Solteiro (a) & $2001,2004,2015,2017,2018$ \\
\hline 3 & 24 & Estudante & Solteiro (a) & $2010,2013,2017,2018$ \\
\hline 4 & 22 & Estudante & Solteiro (a) & $2002,2017,2018$ \\
\hline 5 & 40 & Gerente de Vendas & Casado (a) & $2006,2016,2018$ \\
\hline 6 & 33 & $\begin{array}{l}\text { Professora de } \\
\text { Português }\end{array}$ & Casado (a) & $2010,2012,2015,2017,2018$ \\
\hline 7 & 15 & Estudante & Solteiro (a) & 2017,2019 \\
\hline 8 & 25 & Analista de Marketing & Solteiro (a) & $2004,2013,2014,2017,2018$ \\
\hline 9 & 19 & Estudante & Solteiro (a) & 2016,2018 \\
\hline 10 & 17 & Estudante & Solteiro (a) & 2018,2019 \\
\hline 11 & 45 & Gerente de Marketing & Casado (a) & $2015,2017,2019$. \\
\hline 12 & 22 & Analista de Trade & Solteiro (a) & $2005,2010,2017,2019$ \\
\hline 13 & 38 & Gerente de Loja & Divorciado (a) & 2016,2019 \\
\hline 14 & 25 & Técnico de Informática & Solteiro (a) & 2015,2019 \\
\hline 15 & 24 & Estudante & Solteiro (a) & 2014,2016 \\
\hline 16 & 16 & Estudante & Solteiro (a) & $2007,2010,2016,2018$ \\
\hline 17 & 28 & Analista de Marketing & Solteiro (a) & 2018,2019 \\
\hline
\end{tabular}

Fonte: Elaborado pelo autor

\subsection{Procedimento de coleta dos dados}

Para essa pesquisa, a coleta de dados foi feita através de entrevistas em profundidade, que consistem em entrevistar apenas um indivíduo pessoalmente com o auxílio de um roteiro baseado no referencial teórico, a fim de entender melhor os seus comportamentos e pensamentos.

As entrevistas foram guiadas por um roteiro de entrevistas (disponível no Apêndice 1), com perguntas pautadas na metodologia de incidentes críticos, que busca entender a evidência da qualidade do serviço do ponto de vista do consumidor no "momento da verdade", isto é, no momento em que o cliente está em contato direto com a empresa, através dos funcionários (BITNER; BOOMS; MOHR, 1994). O roteiro foi testado com duas pessoas, a fim de analisar se as perguntas estavam claras o suficiente para os entrevistados entenderem e responderem adequadamente. 
As entrevistas foram feitas pessoalmente e iniciadas com uma breve apresentação do objetivo do estudo. A fim de obter considerações mais detalhadas, as pesquisas foram registradas em gravações de áudio, com o conhecimento e aprovação dos respondentes.

\subsection{Processamento de análise dos dados}

As informações obtidas nas entrevistas foram consolidadas e transcritas para uma planilha utilizando o programa Microsoft Excel.

Para cada aba, foram inseridas todas as respostas de uma respectiva pergunta; dessa maneira, na Aba 1, por exemplo, teriam as respostas de todos os entrevistados referente à pergunta 1 e assim por diante. Como a presente pesquisa é de cunho qualitativo, o objetivo não era contabilizar as respostas, mas sim organizá-las para facilitar a análise.

Tal organização permitiu uma maior comparação entre o referencial teórico e as respostas das entrevistas, de forma a facilitar a busca por semelhanças e diferenças entre os relatos dos entrevistados e quais temas eram abordados com maior frequência.

O Apêndice 2 contém as respostas de cada entrevistado referente a todas perguntas.

\subsection{Limitações da metodologia}

Qualquer pesquisa possui métodos que podem apresentar limitações. Assim, serão definidas as principais delimitações das metodologias utilizadas na pesquisa: qualitativa, exploratória, incidentes críticos e entrevistas em profundidade.

No que se refere ao fato de ser exploratória e contar com entrevistas em profundidade, depende-se da cooperação dos entrevistados, uma vez que estes podem influenciar os resultados por estarem desmotivados, por não terem compreendido corretamente a pergunta (GIL, 2008). Ainda, é possível que tenha tendência nas respostas devido ao fato dos respondentes terem um grau de afinidade com a pesquisadora, visto que foram entrevistados grupos próximos por questão de acessibilidade. 
Além disso, por ser uma pesquisa qualitativa, é necessário estar atento para não generalizar os dados, segundo Zikmund (2006), visto que é uma pesquisa limitada a uma pequena escala e pode não corresponder com o restante da sociedade.

Por fim, é possível ainda que ocorra um grau de subjetividade na interpretação dos dados devido ao grau de afeto e envolvimento da pesquisadora com o tema de pesquisa. 


\section{Análise dos resultados}

Este capítulo é organizado em quatro seções, que apresentam os principais resultados alcançados na pesquisa de campo, de modo que fosse possível entender a percepção e a atitude dos consumidores sobre o atendimento da Disney e o papel dos funcionários. A primeira seção analisa as respostas referentes às impressões sobre a Disney. Em seguida, é feita uma análise com enfoque sobre o incidente crítico ocorrido na Disney. Em terceiro, são apresentadas a percepção das pessoas que estavam junto aos entrevistados durante o incidente. Por último, discute-se as visões dos entrevistados sobre a Disney após o incidente.

\subsection{Impressões sobre a Disney}

Para iniciar a entrevista, foram analisadas as primeiras impressões dos entrevistados em sua chegada ao parque da Disney. Praticamente todos citaram a "magia" e a "organização" da empresa, e demonstraram "grande emoção" com a importância que a empresa dá aos detalhes, beirando a "perfeição", como diz o Entrevistado 9 no trecho a seguir:

Minha primeira impressão quando cheguei lá foi de realmente estar entrando em um filme da Disney. De ver todos os detalhes, tudo muito perfeito. Todas as coisas no lugar encaixaram, tanto os funcionários e 0 atendimento deles, quanto a aparência e os detalhes das lojas. Tudo muito perfeito (Entrevistado 9).

Outro aspecto importante foi a perfeição dos parques no que tange às características sensoriais, que, de acordo com Krishna (2010), podem acentuar as atitudes, as percepções e a satisfação dos consumidores. Foram comentados aspectos como a limpeza, a disponibilidade e aparência dos funcionários, os cheiros e as músicas do local. Segundo Hoyer e Mclannis (2011), esses estímulos são as formas de aumentar a relevância da informação, isto é, através das necessidades, dos valores e das emoções dos consumidores. Percebe-se, 
nos comentários dos Entrevistados 16 e 17, como sua percepção foi impactada por esses estímulos:

É difícil descrever a emoção, sabe? Eu fui pela primeira vez quando era pequena ainda, mas lembro de ter ficado tão deslumbrada com tudo que estava vendo. Era tudo tão colorido, as pessoas fantasiadas. Parecia um sonho. Um cheiro bom, com música. Parecia que dava para enxergar felicidade (Entrevistado 16).

Reparei bastante na organização de lá e felicidade das pessoas. Todo mundo organizando tudo, as filas, lixeiras, tudo limpo. Com funcionários em todo lugar para te ajudar, sorrindo. O som das risadas das pessoas e das músicas de fundo. $O$ cheiro de comida boa. As pessoas fantasiadas. Tudo tão temático nos mínimos detalhes. Um lugar incrível, de fato, beirando a perfeição (Entrevistado 17).

A apresentação dos funcionários e do próprio parque dizem muito a seu respeito pois, como cita Solomon (2008), a exposição é o primeiro estágio perceptivo que poderá envolver o consumidor, prendendo sua atenção - ou não ao estímulo que lhe é apresentado. Percebe-se que essa primeira impressão dos entrevistados tem forte relação com o estímulo visual, como cita o entrevistado 9:

Minha primeira impressão quando cheguei lá foi de realmente estar entrando em uma filme da Disney. De ver todos os detalhes, tudo muito perfeito. Todas as coisas no lugar encaixaram, tanto os funcionários e 0 atendimento deles, quanto à aparência e os detalhes das lojas. Tudo muito perfeito. (Entrevistado 9)

Portanto, analisando as respostas sobre as primeiras impressões junto ao processo perceptivo (HAWKINS, MOTHERSBAUGH, BEST, 2007), a Disney, pelo seu cuidado com o parque e a educação e aparência dos funcionários, consegue ativar o início desse processo, que é a exposição e a sua fase intermediária, que é a de atenção.

Quando questionados sobre o que consideram um bom atendimento, os pontos que os entrevistados mais ressaltam como importantes são o fato de 
entenderem as necessidades dos clientes e se colocarem no lugar deles. Além disso, também citam a atenção focada e personalizada aos clientes, a disposição em ajudá-los e ser sempre muito educado, o que se relaciona com os pontos que Zeithaml, Bitner e Germler (2014) citam ser essenciais para os empregados: ter inteligência emocional e ter emoções consonantes com as desejadas pelas organizações, sendo cordiais, gentis e empáticos. Essa percepção do funcionário mostra-se na resposta da entrevistada 2: "Para começar com educação, gentileza. Que resolva meu problema, entenda meu lado e busque realmente resolver o que aconteceu, que me dê a melhor experiência possível".

Após o questionamento sobre o bom atendimento, foi perguntado aos entrevistados se acreditam que a Disney é uma referência em bom atendimento. Todos os respondentes percebem que a empresa valoriza muito o papel do funcionário e, por isso, investe em seu treinamento. Sabendo que a linha de frente é o elemento mais visível do serviço, Lovelock (2006) indica que os funcionários devem ser a parte essencial da marca. Na visão dos entrevistados, a Disney "trata muito bem" seus empregados e os prepara para oferecer o melhor serviço possível, como notam os entrevistados 5 e 14:

Acho que sim, ela é diferente de qualquer outro lugar. Já viajei para outros lugares, mas não é que nem a Disney. É tudo uma magia que tem em torno que faz toda a diferença (Entrevistado $5)$.

Com certeza. A própria definição de bom atendimento. Todos os funcionários são super bem treinados, educados, sempre sorrindo e extremamente solícitos e prontos para atender a gente como se fôssemos da família deles (Entrevistado 14).

Percebe-se, portanto, que a Disney é referência quando se trata de atendimento e, por isso e outros fatores, é uma empresa reconhecida mundialmente. De acordo com Berry (1999), essa valorização e investimento dos funcionários é uma vantagem competitiva para empresas se tornarem um sucesso. 


\subsection{Incidentes Crítico na Disney}

Nesta seção, serão discutidos os incidentes críticos relacionados ao atendimento dos parques da Disney. A maioria dos respondentes citou alguma experiência que tenha sido positiva para eles e que aconteceu recentemente. De maneira geral, os incidentes críticos citados pelos entrevistados giravam em torno de perda de objetos, como um brinquedo, ou um item mais pessoal, como, por exemplo, uma mochila ou um celular. Outros incidentes que também apareceram nos relatos foram manutenções inesperadas, recebimento de presentes, além de desconhecimento sobre o funcionamento da fila, dos horários dos serviços do parque, dos brinquedos e até mesmo sobre o próprio parque.

A maior parte dos relatos mostra que os incidentes críticos se relacionam com o fato de algum funcionário ter feito uma ação que não só resolveu algum problema, mas que também foi além das expectativas dos clientes, surpreendendo-os de maneira agradável, como cita o entrevistado 5:

Foi uma experiência bem positiva na verdade. Eu estava com minha mãe no banheiro e ela sempre usou muitos anéis na mão e sempre os tira para lavar a mão. Na hora que ela de lavar a mão, uma funcionária que estava passando acabou esbarrando nela e o anel caiu no ralo na hora que ela estava tirando. A funcionária pediu mil desculpas e disse que iria resolver, só precisava que a gente aguardasse uns minutinhos. Ela ligou no walkie-talkie dela e chamou alguém da manutenção, não entendi muito bem o inglês dela, acho que elas estavam falando por código também. Enfim, em cinco minutos veio uma outra funcionária com vários equipamentos, abriu o ralo e conseguiu resgatar 0 anel da minha mãe. Ela perguntou os nossos nomes, disse que iria lavar o anel e pediu para que na volta nós passássemos no Guest Relations para pegar o anel. Ao fim do parque, quando fomos lá, eles entregaram o anel numa caixinha linda da Minnie. Minha mãe e eu ficamos super felizes.

Apenas um entrevistado citou uma experiência negativa na Disney com relação ao atendimento, ficando insatisfeito com o tratamento distante do personagem e da grosseria do funcionário, como cita o trecho abaixo: 
Tive uma experiência bem ruim. Acho que vou ser uma das únicas a dizer isso, inclusive. Enfim, o que aconteceu foi que estava na fila com minha filha para conhecermos o tão esperado Pinóquio, não sei porque mas minha filha queria muito era conhecer o Pinóquio, mais do que o Mickey. Chegou nossa vez e ela foi correndo abraçar o Pinóquio e ele meio que desviou, achei estranho. Quando foi tirar foto, ele ficou super distante, nem tocou na gente. Fui reclamar com a moça da fila e ela foi super grossa dizendo que ele não era obrigado a nada, fiquei chocada com a reação e bem chateada. Só queríamos um abraço com o Pinóquio. Saímos de lá bem cabisbaixas mesmo (Entrevistado 13).

Foi perguntado aos entrevistados quais circunstâncias levaram ao incidente crítico. A maior parte dos entrevistados percebe que o principal motivo foi um erro causado por eles próprios, mas que foi resolvido por uma ação de um funcionário, que teve a boa vontade de querer resolvê-la. Este ponto está relacionado com o conceito de extremidade da atitude (ENGEL; BLACKWELL; MINIARD, 2005), isto é, a intensidade pela qual a pessoa gosta de um produto ou serviço ou de uma marca influencia na sua atitude. Assim, diversas pessoas, por gostarem da Disney, tendem a entender que a causa do problema não poderia ter sido culpa da empresa, transferindo essa responsabilidade para si. Alguns entrevistados, entretanto, passaram por casos diferentes, nos quais culpam os funcionários pelo incidente crítico. Os relatos a seguir ilustram esses dois casos:

O fato do Pinóquio ser distante e a funcionária da fila grosseira. (Entrevistado 13)

A minha falta de atenção e porque estava feliz de estar realizando um sonho. (Entrevistado 15)

O funcionário ter feito algo além do esperado. Ele ter percebido uma criança no meio e ter decidido fazer algo com ela (Entrevistado 17)

Praticamente todos os entrevistados que relataram terem tido uma boa interação com o atendente quando ocorreu o incidente crítico afirmaram que os funcionários conseguiram se colocar no lugar dos respondentes e foram 
solícitos, fazendo tudo que estava a seu alcance para resolver o problema. Citam, por exemplo, como os funcionários os acompanharam durante o processo até a resolução do problema, entregando objetos perdidos e até mesmo oferecendo presentes, como o fast pass, para alegrar os clientes. Ao analisar as respostas sobre a interação, foi possível relacioná-las ao componente afetivo da atitude, pois, segundo Solomon (2016), esse componente diz respeito a como um consumidor se sente em relação a algo e, sendo assim, os consumidores possuem sentimentos positivo ao gostarem da relação que tiveram com os funcionários durante o incidente. De maneira geral, os respondentes perceberam que os funcionários solucionaram o problema através das ações citadas.

Este ponto relaciona-se com o conceito de atitude, isto é, se esse indivíduo responderá de forma favorável ou desfavorável a algum estímulo (SOLOMON, 2016). A maioria dos respondentes respondeu de maneira favorável à interação com os funcionários, agradecendo-os por sua ajuda: "Foi ótima, tanto na atração quanto nos achados e perdidos. Foram super atenciosos e fofos. Me ouviram e trataram do caso como se fosse de um conhecido deles (Entrevistado 1)".

Essa boa relação entre funcionário e cliente também fica visível quando se perguntou o que cada uma das partes falou quando o incidente ocorreu. As conversas entre ambas as partes pareceram bem claras e respeitosas, com os funcionários sendo empáticos e explicando da melhor maneira possível e os clientes sempre se mostrando imensamente agradecidos ao final, conforme indica o entrevistado 5 :

Quando o anel caiu, a funcionária pediu mil desculpas e nós dissemos que não havia problema nenhum. Ela perguntou se poderíamos esperar alguns minutos que ela iria tentar resolver. Ficamos conversando sobre a viagem, ela perguntou se estávamos gostando enquanto tentavam tirar o anel. Quando finalmente tiraram, ela perguntou se poderíamos buscar ele no Guest Relations quando fôssemos embora para ela limpar o anel. Agradecemos bastante e dissemos nossos nomes para na hora de buscar deixarem reservado para a gente. No final do parque, fomos lá e a moça que entregou para a gente foi super gentil também, nos desejou uma ótima viagem. (Entrevistado 5) 
Quando perguntados sobre o que levou o funcionário a lhes atender, a maioria dos entrevistados percebeu que seria a empatia e a capacitação em atendimento oferecidos pela Disney, conforme os entrevistados 1, 5 e 11 afirmam:

Acho que tem a ver com a cultura da Disney, de atender todos do melhor jeito possível e fazer o possível para termos a melhor experiência. (Entrevistado 1)

Acredito que eles são treinados para isso mesmo, para ir além das nossas expectativas. (Entrevistado 5)

A empatia da funcionária com toda certeza, sua generosidade e educação. (Entrevistado 11)

\subsection{Relatos dos acompanhantes dos entrevistados durante 0 Incidente}

A maioria dos respondentes estava acompanhado de família ou de amigos no momento do incidente crítico. No que tange à atitude desses acompanhantes, de maneira geral, foi positiva em relação à resolução do incidente e semelhante à dos próprios respondentes, como cita o entrevistado 2 :

Tava com outras duas amigas. E a gente achou bem legal ele ter tido essa iniciativa de ir procurar, ao invés de só falar que tinha perdido. E tentar contornar ainda a situação, me oferecendo o cupom. (Entrevistado 2)

A maior parte dos acompanhantes dos respondentes também se mostraram satisfeitos com a resolução do problema dos entrevistados. Segundo os respondentes, suas famílias e amigos enfatizaram o bom atendimento e o preparo do funcionário, relatando as ações dos funcionários como sendo de simpatia, compreensão e gentileza e também de entenderem quais ações que são as melhores para serem tomadas sem deixar de seguir as regras. Além disso, a maior parte das pessoas que acompanhavam os entrevistados comentaram sobre o incidente ocorrido e a atitude do funcionário com outras 
pessoas, destacando como os funcionários não ignoraram o problema e buscaram resolvê-lo, como descreve o entrevistado 1 :

No momento eu estava com minha amiga Livia. Mas o resto do grupo ficou sabendo depois e ficou todo mundo chocado com a situação, com o cuidado e a importância que deram pra uma coisa que acontece com todo mundo e não é responsabilidade deles. (Entrevistado 1)

Para Rocha, Ferreira e Silva (2012), a atitude é composta por três componentes: cognição, afetiva e comportamental. Ao entendermos o que os acompanhantes dos respondentes disseram, podemos relacionar com o componente afetivo, isto é, aquele que afeta os sentimentos e as emoções. Percebe-se que os acompanhantes ficaram gratos com a ação dos funcionários e que isso foi algo que também impactou a viagem deles, como cita o entrevistado 11:

Ficamos muito emocionados e gratos pela atitude dessa funcionária. Minha mulher até chorou de emoção. Até hoje, a gente comenta sobre esse momento incrível, de como a funcionária fez algo que mudou completamente nossa viagem e trouxe tanta felicidade (Entrevistado 11).

Outro ponto que o entrevistado 1 citou como importante foi o fato de os funcionários não tentarem se aproveitar de uma situação e, por exemplo, pegarem o objeto perdido caso achassem e por não terem cobrado alguma taxa por o terem achado. As pessoas que estavam acompanhando o entrevistado ficaram surpresas e elogiaram a empresa como um todo:

Todo mundo falou que a Disney é extremamente atenciosa e fui supercuidadosa, e também que dei muita sorte porque ninguém agiu de má fé. Porque passam muitas pessoas lá e ninguém pegou o celular. $E$ não só isso, os próprios funcionários da Disney não pegaram o celular. Porque acontece muito isso dentro de estabelecimentos né, de funcionário pegar? Existem milhares de funcionários lá, e nenhum deles pegou, foram superatenciosos, ligaram para avisar e ainda mandaram para o hotel, sem cobrar nada. Eles mostraram real que se importaram com minha perda e muito 
estabelecimento está nem aí, até porque essa é a regra né. Até mesmo regra deles, que eles não se responsabilizam, mas mesmo assim eles deram total atenção (Entrevistado 1).

As pessoas que estavam acompanhando os entrevistados faziam comentários positivos sobre a Disney e o seu atendimento, de maneira geral. Isso reforça o que Zeithaml, Bitner e Gremler (2014) afirmam sobre os funcionários personificarem a empresa aos olhos do cliente, isto é qualquer comportamento do funcionário influencia na maneira como eles enxergam a empresa Disney como um todo.

\subsection{Opiniões após o incidente crítico}

Quando questionados se acreditam terem recebido um tratamento personalizado, praticamente todos os respondentes consideraram ter tido uma atenção especial para o seu caso. De acordo com Hoyer e McLannis (2011), os consumidores tendem a dedicar mais atenção aos estímulos quando são relevantes pessoalmente, mais agradáveis, mais surpreendentes e fácil de processar. Por isso, quando se tem um atendimento customizado, clientes tendem a ter uma atitude mais positiva, como afirmam os entrevistados 6 e 11 abaixo:

Com certeza. Ele nos acompanhou durante todo processo e ficou brincando com minha filha que não estava entendendo nada da situação porque ainda é muito pequena. (Entrevistado 6)

Nossa, foi extremamente personalizado. Ela poderia ter passado direto pela gente, mas ela parou e perguntou o que havia de errado. Quando soube, os levou para resolver e deu um presente magnífico para minha filha. Ela tratou nosso caso como único. (Entrevistado 11)

Além disso, pode ser percebido que os funcionários, devido ao seu treinamento, possuem um padrão de atendimento com regras e sempre a seguem detalhadamente. Esse modelo é percebido pelo entrevistado 1, quando diz que o atendimento é personalizado por ser uma regra Disney: "Assim, foi 
personalizado. Mas acho que é o padrão Disney mesmo de você tratar a pessoa super bem".

A maior parte dos respondentes relaciona o fato de ter tido uma experiência positiva durante o incidente crítico com uma ação do funcionário, que demonstrou compreensão pela situação e foi generoso e gentil, como percebem os entrevistados 3, 16 e 17:

Foi positiva porque o funcionário se atentou ao fato do que eu estava fazendo, ele poderia nem ter percebido ou escolhido não tomar uma atitude sobre o que eu fiz. (Entrevistado 3)

A funcionária ter sido empática com nossa situação e ter oferecido algo para diminuir nossa tristeza. (Entrevistado 16)

A gentileza e percepção do funcionário. Ele foi tão fofo de ter ido até a gente para realizar algo incrível. (Entrevistado 17)

Outro ponto que reforça a percepção positiva dos respondentes quanto ao atendimento Disney é quando são questionados se o funcionário conseguiu resolver o problema. Uma parte identifica que o erro foi culpa do próprio respondente ou de algum outro fator externo, mas de maneira geral entendem que os funcionários conseguiram contornar a situação e tornar aquilo uma experiência positiva, como afirmam os entrevistados 11 e 12:

O erro não foi especificamente dela, mas quando ela soube o que aconteceu fez de tudo para resolver. Foi super solícita e atenciosa conosco. (Entrevistado 11)

Com certeza. Ela contornou a situação, explicou de maneira extremamente educada e ainda deu um presente para que ela não chorasse. Foi um alívio enorme. (Entrevistado 16)

A parte dos respondentes que entendeu que o erro foi causado por um funcionário da Disney entende que esses indivíduos admitiram o seu erro, conseguindo resolver a situação de forma gentil, como descreve o entrevistado 5: 
A funcionária pediu mil desculpas pelo erro de ter esbarrado, mas conseguiu resolver o problema de maneira excelente. Conseguimos $o$ anel e ainda veio numa caixinha super arrumadinha. (Entrevistado 5)

Os pontos apontados pelos respondentes mostram que existe um padrão positivo de atendimento da Disney. E que, apesar de ocorrerem algumas divergências, como no caso da Entrevistada 13, que não teve uma experiência positiva, em sua maior parte os clientes se sentiram satisfeitos. Além disso, percebe-se também como os entrevistados relacionam esse bom atendimento como uma prática cotidiana da Disney, oferecendo uma vantagem competitiva para a empresa por ser referência nesse assunto.

Por fim, a percepção da marca Disney, com base nos princípios de Hawkins, Mothersbaugh e Best (2007), mostram que a marca é bem conhecida entre os entrevistados como uma que oferece um bom atendimento. Percebe-se que os funcionários cumprem com os requisitos para que os consumidores tenham atitudes positivas do serviço, o que, segundo Schneider e Bowen (1993), seria formadas a partir de: garantia do funcionamento dos equipamentos e processos, atendimento com prontidão, transpassar credibilidade, prestar atenção e compreender as necessidades dos clientes e estar com vestimentas adequadas ao ambiente. 


\section{Conclusões e recomendações para novos estudos}

O presente estudo teve como objetivo analisar a percepção e a atitude de consumidores em relação ao atendimento oferecido por funcionário da Disney a seus convidados. Para isso, foi feita uma pesquisa qualitativa por meio de entrevistas de profundidade com 17 consumidores que já tenham visitado aos parques da Walt Disney World, em Orlando, pelo menos duas vezes nos últimos cinco anos. A partir da análise das respostas dadas, é possível chegar a algumas conclusões. No capítulo atual, serão expostas as considerações finais dessa pesquisa, as implicações gerenciais e, por último, recomendações para novos estudos.

Percebeu-se primeiramente que a percepção que os entrevistados possuem dos parques é homogênea, todos ficam impressionados com a perfeição dos detalhes que tornam o momento de estar no parque algo ainda mágico. É por isso que os parques da Disney estão em primeiro lugar na lista de melhores parques temáticos do mundo, sendo conhecido globalmente e trazendo visitantes internacionais diariamente para conhecer esse mundo tão mágico (AECOM, 2017).

No que tange ao incidente, de maneira geral foram relatados como sendo experiências positivas. Por mais que tenham iniciado de maneira infeliz, como a perda de algum objeto, ao final praticamente todos entrevistados relataram ter tido um final feliz no estilo Disney. O motivo desse "e viveram felizes para sempre" se dá principalmente pelo atendimento dos funcionários. Foi percebido de maneira quase análoga, que os empregados conseguiram resolver os incidentes trazendo total satisfação não só para os entrevistados, como também para as pessoas que os acompanhavam.

Além disso, dois pontos relatados reforçaram a visão positiva dos consumidores sobre a empresa: uma boa interação com os funcionários, que mostraram-se generosos e educados, e um atendimento personalizado. Esssas observações são resultado do trabalho que a Disney têm ao treinar seus "cast members" (em português, elenco) para servir com arte, contando com mais de 70.000 mil funcionários capacitados e treinados para atender a todos da melhor maneira possível (WDW News, 2014). 
Desse modo, todos entrevistados percebem a Disney como uma referência em atendimento, sendo de acordo com Berry (1999) uma vantagem competitiva e estimulante para a fidelidade dos clientes. De maneira geral, percebe-se uma atitude positiva dos consumidores, sendo uma marca reconhecida por trazer satisfação e magia para seus convidados.

\subsection{Implicações gerenciais}

Com base nas análises e considerações anteriormente apresentadas, recomendam-se as seguintes ações gerenciais para a Disney e outras empresas que busquem assertividade em atendimento.

Considera-se relevante continuar com a intensa capacitação dos funcionários, visto que quando bem treinados exercem influência dos consumidores sobre a marca como um todo. Além disso, também devem estar preparados para solução de problemas e ser sempre gentis a fim de evitar casos em que os consumidores se sentem chateados ou ameaçados com atitudes de grosseria, por exemplo.

Recomenda-se também uma maior atenção a comunicação da empresa, visto que foram relatados problemas de desconhecimento sobre manutenção. Sugere-se que os sites, aplicativos e ambientes de informação estejam sempre atualizados.

Por fim, entende-se também a importância de incentivar que os consumidores relatem caso tenham algum problema para que este possa ser corrigido da melhor maneira possível. Dessa maneira, evita-se que as pessoas guardem o problema e se sintam frustradas por não terem conseguido solucionálo.

\subsection{Sugestões de futuros estudos}

Como desdobramentos futuros, seria interessante utilizar de uma maior amostra de respondentes com a seleção de um público mais diversificado, a fim de identificar outras percepções à respeito do atendimento Disney.

Outra abordagem interessante seria aprofundar o estudo diferenciando os perfis de consumo. Por exemplo diferenciar as percepções de pessoas que já visitaram mais de quatro vezes daqueles que foram apenas duas, para 
compreender as semelhanças e diferenças entre quem já foi muitas vezes e quem não foi. Outro perfil que pode trazer diferentes perspectivas é o das pessoas que foram apenas como visitantes daquelas que tiveram experiências como cast member.

Por fim, outra possível recomendação para estudos futuros seria repetir a análise depois de um tempo e comparar com a feita para analisar se as percepções e atitudes sobre o atendimento Disney continuam sendo o mesmo. 


\section{Referências Bibliográficas}

ALLEN, M.; MONNIER, A. The Interactive Effect of Cultural Symbols and Human Values on Taste. Journal of Consumer Research, v. 35, p. 294-308, Aug. 2008.

BITNER, M. J.; BOOMS, B. H.; MOHR, L. A. Critical Services Encounters. Journal of Marketing v.58, p. 95-106. 1994.

DISNEY INSTITUTE. $O$ jeito Disney de encantar os clientes. $1^{\circ}$ edição, São Paulo: Saraiva, 2011.

ELLEN, P.S; BONE, P.F. Does it matter if it smells? Olfactory Stimuli as Advertising Executional Cues. Journal of Advertising, v. 27, p. 29-40. dec. 1998.

GIL, A.; Métodos e técnicas de pesquisa social. 6.ed. São Paulo: Editora Atlas,2008.

HOYER, Wayne; MACLNNIS, Deborah. Comportamento do Consumidor. 5. ed. Cengage Learning, 2011.

HORNIK, J. Tactile Stimulation and Consumer Response. Journal of Consumer Research, v. 19, p. 449-458, dec. 1992.

INTERBRAND. Best Global Brands 2018 Rankings, 2018.

KRISHNA, May O. Lwin; MORRIN M. Product Scent and Memory. Journal of Consumer Research v.37, p. 57-67. 2010.

L.L. Berry; Discovering the Soul of Service. New York: The Free Press, 1999 ROCHA, Angela; BRANTES, Jorge; FERREIRA, Jorge. Administração de Marketing. São Paulo: Atlas, 2012.

SCHIFFMAN, Leon G.; KANUK, Leslie Lazar. Comportamento do consumidor. 6. ed, Rio de Janeiro: LTC, 2000.

SCHNEIDER, B., BOWEN, D. E. The Service Organization: Human Resources Management Is Crucial. Spring, 1993.

TEA/AECOM. 2017 Theme Index and Museum Index: The Global Attractions Attendance Report Publisher. Themed Entertainment Association (TEA), 2017. WALT DISNEY COMPANY. Ano fiscal 2018. Relatório Financeiro Anual, 2018. WALT DISNEY COMPANY. Our Businesses. Disponível em <https://www.thewaltdisneycompany.com/about/\#our-businesses> Acesso em: 17 abr. 2019.

WALT DISNEY WORLD NEWS. Fact Sheets. Disponível em < 
https://wdwnews.com/fact-sheets/2014/10/31/walt-disney-world-fun-facts/> Acesso em: 20 abr. 2019.

ZEITHAML, V.A.; BITNER, M. J.; GREMLER, D.D. Marketing de serviços: a empresa com foco no cliente. 2 ed. Porto Alegre: Bookman, 2003. ZIKMUND, W. G. Princípios da pesquisa de marketing. São Paulo: Thomson, 2006. 


\section{Apêndice 1}

\section{Roteiro para entrevistas}

Bom dia/boa tarde,

Sou aluna do curso de Administração da PUC Rio e gostaria de entrevistar você para o meu trabalho de conclusão de curso. O objetivo da minha pesquisa é entender a percepção e a atitude dos consumidores em relação ao atendimento do funcionário oferecido pela Disney aos seus convidados. Por favor responda com a maior sinceridade, lembre que não existem respostas certas ou erradas; o importante é entender a sua opinião a respeito do assunto.

Poderia gravar a nossa entrevista para que eu obtenha o maior nível de detalhes? As informações fornecidas serão utilizadas apenas para fins acadêmicos. Se tiver alguma dúvida ou quiser acrescentar alguma informação que não foi perguntada, fique a vontade para me interromper.

Podemos começar?

1. Você já foi a algum parque da Disney em Orlando (Magic Kingdom, Epcot, Hollywood Studios ou Animal Kingdom)?

2. Quantas vezes você já foi à Disney? Em quais anos?

3. Qual foi a sua primeira impressão ao chegar? O que te chamou atenção? (atenção)

4. Durante sua visita, você teve algum incidente relacionado a atendimento muito bom ou ruim? Conte como foi.

5. Quando o incidente aconteceu?

6. Você estava sozinho ou acompanhado? Se estava acompanhado, o que os outros acharam do incidente?

7. O que você e as pessoas que estavam te acompanhando falaram depois do incidente? (atitude) 
8. Quais circunstâncias você percebe que levaram para essa situação? (percepção)

9. Como foi sua interação com o atendente? (atitude)

10. O que você falou para o funcionário e o que ele falou para você?

11. Teve algum contato físico?

12. Você considera que o atendimento tenha sido personalizado? (percepção)

13. O que ocorreu para a experiência ter sido positiva ou negativa? (atitude)

14. O que você percebeu que levou o funcionário te atender? (percepção)

15. Você percebeu que o funcionário admitiu o erro e tentou resolver? Ele conseguiu resolver?

16. O que você considera como um bom atendimento? (papel funcionário)

17. Você acredita que a Disney é referência em atendimento ao cliente? Por que? (papel funcionário)

18. Quantos anos você tem?

19. Qual sua ocupação?

20. Qual seu estado civil? 


\section{Apêndice 2}

\begin{tabular}{|l|l|}
\hline & $\begin{array}{l}\text { 1. Você já foi a algum parque da Disney em Orlando (Magic Kingdom, Epcot, } \\
\text { Hollywood Studios ou Animal Kingdom)? }\end{array}$ \\
\hline 1 & Já sim. Em todos os parques \\
\hline 2 & Sim \\
\hline 3 & Sim \\
\hline 4 & Sim Todos esses \\
\hline 5 & Sim \\
\hline 6 & Sim \\
\hline 7 & Sim, em todos os parques \\
\hline 8 & Sim \\
\hline 9 & Sim. Em todos \\
\hline 10 & Sim, mas só fui no Magic Kingdom e no Epcot \\
\hline 11 & Sim, em todos esses e também na Disneyland da Califórnia \\
\hline 12 & Sim, em todos \\
\hline 13 & Já sim. \\
\hline 14 & Yes, em todos esses \\
\hline 15 & Sim \\
\hline 16 & Já fui em todos, menos no Animal Kingdom \\
\hline 17 & Sim \\
\hline
\end{tabular}

\begin{tabular}{|c|c|}
\hline & 2. Quantas vezes você já foi à Disney? Em quais anos? \\
\hline 1 & 4 vezes. Fui em 2014, 2015, 2016 e agora em 2019 \\
\hline 2 & $\begin{array}{l}\text { Só em } 2017 \text { e } 2018 \text { eu fui } 4 \text { vezes. Porque fiz intecâmbio de trabalho lá. Mas fora isso, fui } \\
\text { mais nova em 2001, } 2004 \text { e } 2015\end{array}$ \\
\hline 3 & Fui em 2010, 2013, 2017 e 2018 \\
\hline 4 & Fui ano passado em 2018. E antes em 2017 e 2002 \\
\hline 5 & Fui 3 vezes. 2006, 2016 e 2018 \\
\hline 6 & Já fui umas 5 vezes. Em 2010, 2012, 2015, 2017 e 2018 \\
\hline 7 & Fui em 2017 e 2019 \\
\hline 8 & Fui em 2004, 2013, 2014, 2017 e 2018 \\
\hline 9 & Fui 2 vezes. Em 2016 e 2018 \\
\hline 10 & Fui ano passado e esse ano. Duas vezes em 2018 e 2019 só uma vez \\
\hline 11 & Já fui algumas boas vezes. Fui em 1998, 2002, 2005, 2009, 2013, 2015, 2017 e 2019. \\
\hline 12 & Fui em 2005, 2010, 2017 e 2019 \\
\hline 13 & Em 2016 e início do ano agora. Em 2019 \\
\hline 14 & Fui em 2015 e 2019 \\
\hline 15 & Fui duas vezes, uma em 2014 e outra em 2016 \\
\hline 16 & 4 vezes. Em 2007, 2010, 2016 e 2018 \\
\hline 17 & Fui ano passado e esse ano, 2018 e 2019 \\
\hline
\end{tabular}

3. Qual foi a sua primeira impressão ao chegar? O que te chamou atenção? (atenção) 


\begin{tabular}{|c|c|}
\hline 1 & $\begin{array}{l}\text { Quando cheguei achei tudo muito perfeito. Parece literalmente um mundo de mentira, as } \\
\text { construções perfeitas e absurdas, as pessoas fantasiadas, tudo colorido, real e muito } \\
\text { organizado }\end{array}$ \\
\hline 2 & $\begin{array}{l}\text { Eu acho que parece um conto de fadas, não parece que você está no mundo real. Tudo é } \\
\text { muito coeso, eles fazem você acreditar real que você está num mundo da magia, é tudo } \\
\text { perfeito. E lá tem muitos funcionários, sorrindo, dando bom dia, boa tarde e boa noite. Lá } \\
\text { é super limpo, isso me chamou muita atenção, muito lixo e sempre alguém limpando }\end{array}$ \\
\hline 3 & A quantidade de funcionários sorrindo sempre \\
\hline 4 & $\begin{array}{l}\text { O que eu lembro bastante é que era tudo muito organizado. A fila dos carros no } \\
\text { estacionamento quando você já chega, é extremamente organizada. Os funcionários te } \\
\text { encaminham certinho até o melhor lugar para ficar tudo organzado }\end{array}$ \\
\hline 5 & $\begin{array}{l}\text { Eu acho que tudo. Quando a gente vê a Disney de fora, antes de ir, já imaginamos um } \\
\text { lugar mágico, cheio de coisas incríveis. E quando a gente chega lá, é muito melhor do que } \\
\text { a gente já imaginava. A estrutura, o jeito que as pessoas te tratam, parece que você está } \\
\text { dentro dos fimes, de um conto de fadas. A música também faz toda diferença, dá um } \\
\text { clima todo diferenciado para a experiência }\end{array}$ \\
\hline 6 & $\begin{array}{l}\text { A impressionante qualidade de tudo no parque. E também como a equipe de funcionários } \\
\text { é bem preparada, são queridos e atenciosos. E como os brinquedos funcionam } \\
\text { perfeitamente. }\end{array}$ \\
\hline 7 & $\begin{array}{l}\text { Fiquei chocada quando entrei. Era tudo tão perfeito, todo mundo estava tão feliz. Era uma } \\
\text { atmosfera incrível. Tudo limpo e organizado, vários personagens, funcionários e uma } \\
\text { estrutura incrível }\end{array}$ \\
\hline 8 & $\begin{array}{l}\text { O ambiente como um todo, os cenários que são completamente perfeitos e as pessoas } \\
\text { sempre gentis }\end{array}$ \\
\hline 9 & $\begin{array}{l}\text { Minha primeira impressão quando cheguei lá foi de realmente estar entrando em uma } \\
\text { filme da Disney. De ver todos os detalhes, tudo muito perfeito. Todas as coisas no lugar } \\
\text { encaixaram, tanto os funcionários e o atendimento deles, quanto à aparecência e os } \\
\text { detalhes das lojas. Tudo muito perfeito }\end{array}$ \\
\hline 10 & $\begin{array}{l}\text { Eu já sou velho, e nunca tinha ido. Nunca tinha ligado tanto para isso, sempre soube que } \\
\text { era um lugar legal. Mas quando você chega lá é incrível, mesmo você esperando a } \\
\text { perfeição, eles fazem ainda mais. Fiquei sem palavras. Tudo extremamente organizado, } \\
\text { diferente do Brasil, um monte de gente pra te ajudar, tudo limpo, cheiroso e uns lugares } \\
\text { lindos. Realmente, fiquei impressionado }\end{array}$ \\
\hline 11 & $\begin{array}{l}\text { Na hora que a gente chega já ficamos impressionados com a organização e disposição dos } \\
\text { funcionários para te ajudarem. Tudo extremamente limpo e bonito, com vários } \\
\text { funcionários sempre sorrindo e parecendo felizes de estar lá de verdade }\end{array}$ \\
\hline 12 & $\begin{array}{l}\text { Cheguei achando que estava num mundo da mágia já. Tudo tão lindo, parecia cena de } \\
\text { filme mesmo. Tudo com um cheiro maravilhoso e músicas, gente rindo por todos os } \\
\text { cantos, gente fantasiada. Melhor lugar do mundo }\end{array}$ \\
\hline 13 & $\begin{array}{l}\text { Nossa, tenho nem palavras. Quando cheguei parecia que eu estava sonhando, tudo tão } \\
\text { lindo, cheiroso, limpo, arrumado. Todo mundo feliz, com fantasia. As estruturas incríveis } \\
\text { e tão reais. Um dos lugares mais incríveis que já fui, cheio de detalhe até dizer chega }\end{array}$ \\
\hline 14 & $\begin{array}{l}\text { Minha primeira impressão foi de como eles conseguem incorporar o tema, sabe? O } \\
\text { primeiro parque que eu fui era o Magic Kingdom e ele é dividido por áreas com temas } \\
\text { diferentes, então quando você estava na área por exemplo do futuro, tudo era relacionado } \\
\text { com isso, até os banheiros e chão. E quando você chegava na área principal, era tudo } \\
\text { temático dos Estados Unidos com lojas da época, tinha até cheiro de bolo. E tocando as } \\
\text { músicas em todos os lugares. Tudo limpo, organizado. Cada lugar com as pessoas } \\
\text { fantasiadas de um jeito diferente. Os detalhes lá são incríveis. }\end{array}$ \\
\hline
\end{tabular}




\begin{tabular}{|l|l|}
15 & $\begin{array}{l}\text { Foi uma emoção muito grande porque cheguei naquele barco e aprimeira coisa que eu vi } \\
\text { foi o castelo. Chorei que nem criança. Foi em outubro, então tinha enfeites de Halloween, } \\
\text { tinha várias abóboras gradonas enfeitadas, Mickey e Minnie vestidos de bruxos e estava } \\
\text { tendo um evento de Halloween e de noite tiveram fogos. As pessoas estavam fantasiadas } \\
\text { e isso aumentou a magia do momento. E as comidas estavam temáticas também. Foi } \\
\text { muito legal }\end{array}$ \\
\hline 16 & $\begin{array}{l}\text { É difícil descrever a emoção sabe? Eu fui pela primeira vez quando era pequena ainda, } \\
\text { mas lembro de ter ficado tão deslumbrada com tudo que estava vendo. Era tudo tão } \\
\text { colorido, as pessoas fantasiadas. Parecia um sonho. Um cheiro bom, com música. Parecia } \\
\text { que dava para enxergar felicidade }\end{array}$ \\
\hline 17 & $\begin{array}{l}\text { Reparei bastante na organização de lá e felicidade das pessoas. Todo mundo organizando } \\
\text { tudo, as filas, lixeiras, tudo limpo. Com funcionários em todo lugar para te ajudar, } \\
\text { sorrindo. O som das risadas das pessoas e das músicas de fundo. O cheiro de comida boa. } \\
\text { As pessoas fantasiadas. Tudo tão temático nos mínimos detalhes. Um lugar incrível de } \\
\text { fato, beirando a perfeição. }\end{array}$ \\
\hline
\end{tabular}

\begin{tabular}{|c|c|}
\hline & $\begin{array}{l}\text { 4. Durante sua visita, você teve algum incidente relacionado a atendimento muito } \\
\text { bom ou ruim? Conte como foi. }\end{array}$ \\
\hline 1 & $\begin{array}{l}\text { Eu tava num brinquedo, não lembro o parque agora, na primeira vez que eu fui com um } \\
\text { grupo de amigos. Todos nós tínhamos acabado de comprar um celular, quando lançou o } \\
\text { Iphone 6, se eu não me engano. O celular era novinho, fazia uns três dias que eu tinha } \\
\text { comprado. A gente foi numa atração da Pequena Sereia que têm aqueles banquinhos tipo } \\
\text { teatro, sentamos e o meu celular caiu da minha bolsa. Quando saímos do brinquedo, } \\
\text { procuramos e procuramos o celular, não achamos. A gente tentou voltar para a atração, só } \\
\text { que não podia entrar porque esses teatros e shows, saí um grupo e entra outro } \\
\text { automaticamente. A moça que ficava na frente, foi super educada, explicou para a gente } \\
\text { que não podia mais entrar, porque já tinha gente lá e falou para gente ir lá no Achados e } \\
\text { Perdidos, explicar o que aconteceu que para caso achassem, eles iriam entrar em contato. } \\
\text { A gente já tinha dado como perdido, porque passam milhões e milhões de pessoas no } \\
\text { brinquedo, se acharem o celular com certeza alguém vai pegar. Mas mesmo assim, fui no } \\
\text { Achados e Perdidos, falei como era a capinha do celular, expliquei e o pesssoal foi super } \\
\text { atencioso comigo. Anotaram tudo, fizeram uma ficha minha e pegaram o celular do guia } \\
\text { para ligarem. No dia seguinte de manhãzinha, o pessoal da Disney liga pro guia, falando } \\
\text { que encontraram o celular e que ele estava guardado, não tinha nem } 24 \text { horas que eu tinha } \\
\text { perdido. Eles pediram o endereço do hotel e mandaram para lá, chegou no final da tarde } \\
\text { já, dentro de um pacote da Disney. }\end{array}$ \\
\hline 2 & $\begin{array}{l}\text { Eu estava no último dia de parque que poderia ir durante o intercâmbio. Pra fechar, estava } \\
\text { indo para a aquela montanha-russa da guitarra, no Hollywood Studios, que é do Rolling } \\
\text { Stones. E tava com uma orelinha da Minnie, que acabou caindo durante a ride e só } \\
\text { percebi quando saí. Pedi ajuda de um funcionário, ele entrou e procurou, mas acabou não } \\
\text { achando. Ele viu que eu tinha ficado triste e me deu um cupom para trocar por uma nova } \\
\text { orelhinha, foi um momento bem mágico pra mim. }\end{array}$ \\
\hline 3 & $\begin{array}{l}\text { Foi boa, eu estava indo para a fila da montanha russa dos } 7 \text { anões no Magic Kingdom. Eu } \\
\text { entrei na fila e fui andando, só fui perceber quase no final que eu tinha entrado na fila } \\
\text { errada sem querer, tava na fila do fast pass. Quando vi, voltei tudo para entrar na fila } \\
\text { nova e um funcionário viu o que eu tinha feito e me deu um fast pass para a atração só } \\
\text { pela minha honestidade. Foi incrível, porque a fila estava relativamente grande }\end{array}$ \\
\hline 4 & $\begin{array}{l}\text { Como éramos um grupo grande, sempre ficava naquela discussão de qual percurso era } \\
\text { melhor para fazer dentro do parque, quais atrações iríamos, e outras coisas. Estavámos na } \\
\text { entrada ainda, procurando um mapa em português, mas não tinha. Uma funcionária que } \\
\text { estava escutando nossa discussão, pegou um mapa em português, entregou para a gente e } \\
\text { pediu desculpas por ter acabado já o da nossa língua. Ela era brasileira e ainda deu dicas } \\
\text { para a gente das atrações que deveríamos ir primeiro, porque ficavam mais cheias depois. } \\
\text { Ajudou bastante as dicas dela e o mapa também para irmos logo nos brinquedos }\end{array}$ \\
\hline
\end{tabular}




\begin{tabular}{|c|c|}
\hline 5 & $\begin{array}{l}\text { Foi uma experiência bem positiva na verdade. Eu estava com minha mãe no banheiro e } \\
\text { ela sempre usou muitos anéis na mão e sempre os tira para lavar a mão. Na hora que ela } \\
\text { de lavar a mão, uma funcionária que estava passando acabou esbarrando nela e o anel } \\
\text { caiu no ralo na hora que ela estava tirando. A funcionária pediu mil desculpas e disse que } \\
\text { iria resolver, só precisava que a gente aguardasse uns minutinhos. Ela ligou no walkie } \\
\text { talkie dela e chamou alguém da manutenção, não entendi muito bem o inglês dela, acho } \\
\text { que elas estavam falando por código também. Enfim, em } 5 \text { minutos veio uma outra } \\
\text { funcionária com vários equipamentos, abriu o ralo e conseguiu resgatar o anel da minha } \\
\text { mãe. Ela perguntou os nossos nomes, disse que iria lavar o anel e pediu para que na volta } \\
\text { nós passassemos no Guest Relations para pegar o anel. Ao fim do parque, quando fomos } \\
\text { lá, eles entregaram o anel numa caixinha linda da Minnie. Minha mãe e eu ficamos super } \\
\text { felizes. }\end{array}$ \\
\hline 6 & $\begin{array}{l}\text { Eu tenho uma filha mais nova e quando chegamos no parque, meu marido foi alugar } \\
\text { aqueles carrinhos de criança. Durante o processo, ele precisou assinar um termo e } \\
\text { condições e acabou apoiando a mochila no chão. Quando saímos, ele bem desatento, } \\
\text { acabou esquecendo de pegar a mochila que tinha deixado lá, só que só nos demos conta } \\
\text { tipo } 20 \text { minutos depois. Assim que percebemos, fomos correndo falar com o primeiro } \\
\text { funcionário que vimos e ele foi super atencioso com gente. Ele nos levou ao achados e } \\
\text { perdidos, explicando que havíamos perdido a mocila e o funcionário de lá, também bem } \\
\text { atencioso e educado, disse que não estava lá. Meu marido já nervoso, começou até a ser } \\
\text { mal educado dizendo que tinha que estar lá, mas o primeiro funcionário que estava } \\
\text { acompanhando a gente, gentilmente falou que a mohila poderia estar ainda no mesmo } \\
\text { lugar. Ele fou super solícito e nos levou até o mesmo lugar que estávamos e a mochila } \\
\text { ainda estava lá, paradinha. }\end{array}$ \\
\hline 7 & $\begin{array}{l}\text { Eu fui na minha viagem de } 15 \text { anos com meus amigos ano passado. Estávamos em um } \\
\text { grupo grande esperando na fila do Soarin, um brinquedo no Epcot. Estava beijando meu } \\
\text { namorado e um segurança veio cutucar e fui super grosso com a gente falando que não } \\
\text { era lugar para fazer isso. Assim, entendo a situação, realmente tem criança e é chato, mas } \\
\text { ele não tinha necessidade de cutucar e nem ser grosso. Meu namorado ficou meio } \\
\text { chateado e respondeu falando que ele entendia nosso erro, pediu desculpas mas que o } \\
\text { segurança não precisava ter sido grosso. E por incrível que pareça, o segurança realmente } \\
\text { pareceu estar sem graça, e pediu desculpas para a gente. Nós sorrimos e falamos que } \\
\text { estava tudo bem e que não iria se repetir }\end{array}$ \\
\hline 8 & $\begin{array}{l}\text { Eu e minha família tínhamos fast pass para entrar no Soarin com horário marcado, e } \\
\text { quando estávamos encaminhando para lá, havia acontecido algo no brinquedo que ele } \\
\text { estava em manutenção no momento. Fomos conversar com uma funcionária, já } \\
\text { imaginando que ela diria que perderíamos nossos fast pass. Ela ofereceu outro fast pass } \\
\text { para um horário mais tarde, quando provavelmente o brinquedo já teria voltado a normal. }\end{array}$ \\
\hline 9 & $\begin{array}{l}\text { Então, o que aconteceu comigo foi uma experiência muito boa na primeira vez que eu fui. } \\
\text { Quando eu entrei, veio um fucionário super feliz e perguntou se era a primeira vez que eu } \\
\text { estava vindo ao parque e eu disse que sim e ele me deu um botão. E eu fiquei muito feliz, } \\
\text { porque foi muito do nada que ele me deu esse presente. Foi muito legal ter alguém } \\
\text { prestando atenção em mim, tenho o botão até hoje, foi muito especial para mim. Usei em } \\
\text { todos os parques, e todos os funcionários paravam e conversavam comigo, perguntando } \\
\text { se eu estava gostando. Fez toda diferença para mim }\end{array}$ \\
\hline 10 & $\begin{array}{l}\text { Então, o que aconteceu foi super clichê de Disney. Eu tinha acabado de comprar aquele } \\
\text { sorvete em formato de Mickey e estava super ansiosa para abrir, acabei me epolgando } \\
\text { demais e na hora de puxar a embalagem o sorvete caiu interitinho no chão, não deu nem } \\
\text { para experimentar. Fiquei mega chateada, meio sem reação por um tempo. Ai meu pai } \\
\text { estava se oferecendo para comprar outro que não tinha problema. Quando estava me } \\
\text { encaminhando já para comprar outro, o funcionário da carrocinha de sorvete, me ofereceu } \\
\text { o mesmo sorvete de graça, eu agradeci, ofereci o dinheiro e disse que não precisava. Mas } \\
\text { ele insistiu, sorriu e disse que não podia deixar a magia acabar e falou para aproveitarmos } \\
\text { a viagem. Ficamos super felizes e valeu super a pena porque o sorvete era delicioso. }\end{array}$ \\
\hline
\end{tabular}




\begin{tabular}{|c|c|}
\hline 11 & $\begin{array}{l}\text { Estava com minha mulher, minha filha mais velha e minha filha mais nova que estava } \\
\text { indo pela primeira vez comemorar seu aniversário. No dia da comemoração, fizemos uam } \\
\text { reserva no Be Our Guest, um restaurante super disputado de conseguir reserva com o } \\
\text { tema da Bela e a Fera, a princesa favorita dela. Nós havíamos encomendado um vestido } \\
\text { da Bela, que acabou não chegando a tempo e ela ficou bem chateada com isso. Quando } \\
\text { estava perto da hora de jantar ela começou a chorar bastante e falar que não queria ir sem } \\
\text { estar vestida de Bela. E foi bem nessa hora, que uma funcionária passou e perguntou } \\
\text { porque ela estava chorando tanto. Expliquei toda situação e ela pediu para nós a } \\
\text { acompanharmos até o Guest Relations, chegando lá ela fez uma ligação telefônica. Virou } \\
\text { para gente e disse que o Mickey tinha ligado para ela e que havia preparado um presente } \\
\text { de aniversário para ela. Ela nos levou até uma loja dentro do parque, pegou o vestido e o } \\
\text { sapato da Bela e deu para minha filha. Ficamos extremamente emocionados e } \\
\text { agradecemos muito. Ela sorriu e disse para aproveitarmos nosso jantar, e lá fomos com } \\
\text { nossa filha extremamente feliz. }\end{array}$ \\
\hline 12 & $\begin{array}{l}\text { Eu e minha família estávamos viajando com outro grupo de amigos dos meus pais que } \\
\text { tinha uma filha bem pequenininha ainda. Ela era muito fofa, mas bem mimada e ficava } \\
\text { chorando. Quando a gente estava no Magic Kingdom, ela estava vestida de Branca de } \\
\text { Neve e insistiu para ir na montanha-russa dos sete anões, já que era da princessa favorita } \\
\text { dela. Enfim, fomos para fila, já imaginando que não daria para ela ir. Quando chegamos } \\
\text { lá, não deu outra. Ela precisava ter } 1,02 \text { e na verdade ela tinha apenas } 1 \mathrm{~m} \text {. Enfim, ela já } \\
\text { começou a chorar por causa disso. E o pai dela já estava indo conversar com a } \\
\text { funcionária para ver se conseguia desenrolar da filha dele ir. A funcionária simplesmente } \\
\text { abaixou, ficou na altura dos olhos da criança e falou toda feliz em português mesmo "Oh, } \\
\text { quase esqueci, pricesa! Eu tenho uma amiga que se chama Branca de Neve, sabe quem é? } \\
\text { Então, ela esteve aqui } 5 \text { minutinhos antes e disse que queria falar com você, mas como } \\
\text { não te encontrou, deixou um presente para você" e deu um adesivo da Minnie vestida de } \\
\text { princesa. A filha dele parou de chorar na hora e abriu um sorriso enorme. Agradecemos } \\
\text { bastante a ela por ter conseguido fazer ela parar de chorar e fomos para outro brinquedo } \\
\text { que ela pudesse ir. }\end{array}$ \\
\hline 13 & $\begin{array}{l}\text { Então, tive uma experiência bem ruim. Acho que vou ser uma das únicas a dizer isso } \\
\text { inclusive. Enfim, o que aconteceu foi que estava na fila com minha filha para } \\
\text { conhecermos o tão esperado Pinóquio, não sei porque mas minha filha queria muito era } \\
\text { conhecer o Pinóquio, mais do que o Mickey. Chegou nossa vez e ela foi correndo abraçar } \\
\text { o Pinóquio e ele meio que desviou, achei estranho. Quando foi tirar foto, ele ficou super } \\
\text { distante, nem tocou na gente. Fui reclamar com a moça da fila e ela foi super grossa } \\
\text { dizendo que ele não era obrigado a nada, fiquei chocada com a reação e bem chateada. Só } \\
\text { queríamos um abraço com o Pinóquio. Saímos de lá bem cabisbaixas mesmo. }\end{array}$ \\
\hline 14 & $\begin{array}{l}\text { Eu fui com minhas primas, uma mais velha e outra mais nova. A mais nova foi com o } \\
\text { objetivo praticamente de encontrar a gatinha do Aristogatas, a Marie. Como a gente foi } \\
\text { em excursão, os nossos dias no parque acabam ficando meio engessados e o dia de } \\
\text { encontrar a Marie era o dia do Epcot na parte da França, como havíamos procurado nos } \\
\text { sites. Era nosso último dia de parque e fomos ao tão esperado parque. Chegamos e a } \\
\text { primeira coisa que fizemos foi ir ao Guest Relations perguntar qual era o horário da } \\
\text { personagem, ele disse que ela estaria lá. Fomos até o pavilhão da França e uma } \\
\text { funcionária informou que a gatinha havia se mudado para o Magic Kingdom e não iria } \\
\text { aparecer por lá, Ficamos mega chateados, mas não nos demos por vencidos. Voltamos a } \\
\text { mesma funcionária que atendeu a gente no Guest Relations e contamos o que tinha } \\
\text { acontecido, ela pediu desculpas pela informação errada que havia dado para gente mas } \\
\text { que a gatinha estaria presente no Magic Kingdom no dia seguinte. Explicamos que era } \\
\text { nosso último dia e estávamos mesmo ansiosos por encontrar ela. Quando já estávamos } \\
\text { nos dando por vencido, ela disse que daria um upgrade em nossos ingressos e que } \\
\text { poderíamos passar no Magic Kingdom hoje quando desejarmos. Nós aceitamos mega } \\
\text { felizes, e ela ofereceu os horários que a gatinha iria estar por lá e ainda deu uma pantufa } \\
\text { da gatinha para minha prima. Só faltou ela chorar de tão feliz. Ficamos super felizes }\end{array}$ \\
\hline
\end{tabular}


Meu sonho era ter o bichinho de pelúcia do Stitch, aí eu comprei com a grana que sobrou da viagem depois que voltei de Miami. Quando estava lanchando com minha família, sentamos em um banco e acho que acabei esquecendo a sacola lá e perdi o Stitch. Chorei muito porque não tinha mais dinheiro para comprar outro. Nessa hora, passou um funcionário e perguntou porque estava chorando. Expliquei o que aconteceu e ele disse para eu esperar um pouco ali que já voltava, me deu um pin do Stitch e saiu. Depois de uns 5 minutos, ele voltou trazendo um presente. Quando abri, vi que era o Stitch. Chorei, de novo. Fiquei super feliz. Valeu a viagem

Já tinha ido quando criança para Disney algumas vezes e meu brinquedo favorito sempre foi o Splash Mountain, um de água do Magic Kingdom. Nós planejamos nossa viagem e a primeira coisa que fiz, foi confirmar se haveria alguma manutenção no brinquedo para que nós não deixássemos de ir. No dia do tão aguardado brinquedo, chegamos lá e nos demos de cara com o brinquedo fechado passando por uma manutenção temporária. Fiquei arrasada. Meu pai foi reclamar no Guest e Relations fazer uma reclamação e a moça foi super legal com a gente. Ofereceu fast pass para diversos brinquedos para a nossa família inteira. Por mais que tenha ficado triste de não ir no brinquedo, acabamos conseguindo economizar bastante tempo com os fast pass que eles deram a mais para gente.

Estava com meu tio e meu primo mais novo, quando estávamos procurando um lugar bom para ficar antes da parada começar, um funcionário chamou meu primo e perguntou se ele queria ajudar ele a desligar as luzes do parque para a parada começar. Ele ficou todo feliz e disse que sim. O funcionário pegou uma varinha de uma loja e deu para meu primo, disse para ele falar as palavras mágicas e contar até 3 que as luzes iriam apagar. Meu primo fez isso, e todas as luzes apagaram quando ele chegou no 3. Ele ficou deslumbrado, foi incrível.

\begin{tabular}{|c|l|}
\hline & 5. Quando o incidente aconteceu? \\
\hline 1 & Foi em 2016, quando fui com um grupo de amigos \\
\hline 2 & Foi em 2018, durante o intercâmbio \\
\hline 3 & Foi em 2017 \\
\hline 4 & 2017. Assim que chegamos no Epcot \\
\hline 5 & Em 2016 \\
\hline 6 & 2018 \\
\hline 7 & Em 2019 \\
\hline 8 & Em 2017 \\
\hline 9 & Foi em 2016, na entrada do Magic Kingdom \\
\hline 10 & Foi agora em 2019 \\
\hline 11 & Foi em 2017 \\
\hline 12 & Em 2019 \\
\hline 13 & Férias de Junho de 2019 \\
\hline 14 & Foi em 2015 \\
\hline 15 & Outubro de 2014 \\
\hline 16 & Em 2018 \\
\hline 17 & Início de 2019 \\
\hline
\end{tabular}

\begin{tabular}{|c|l|}
\hline & $\begin{array}{l}\text { 6. Você estava sozinho ou acompanhado? Se estava acompanhado, o que os outros } \\
\text { acharam do incidente? }\end{array}$ \\
\hline 1 & $\begin{array}{l}\text { No momento eu estava com minha amiga Livia. Mas o resto do grupo ficou sabendo } \\
\text { depois e ficou todo mundo chocado com a situação, com o cuidado e a importância que } \\
\text { deram pra uma coisa que acontece com todo mundo e não é responsabilidade deles. }\end{array}$ \\
\hline 2 & $\begin{array}{l}\text { Tava com outras duas amigas. E a gente achou bem legal ele ter tido essa iniciativa de ir } \\
\text { procurar, ao invés de só falar que tinha perdido. E tentar contornar ainda a situação, me } \\
\text { oferecendo o cupom }\end{array}$ \\
\hline
\end{tabular}




\begin{tabular}{|c|c|}
\hline 3 & $\begin{array}{l}\text { Estava com minha família. Acharam muito legal a atitude e eles também ganharam o fast } \\
\text { pass }\end{array}$ \\
\hline 4 & Estava com um grupo grande, todo mundo ficou super supreendido com a atitude dela \\
\hline 5 & $\begin{array}{l}\text { Estava com minha mãe. Meu pai e marido estavam nos esperando fora do banheiro. Nós } \\
\text { ficamos hiper felizes, foi uma atitude fora do comum. A funcionária poderia ter só } \\
\text { pedido desculpas e seguido com isso, mas ela fez questão de não só achar o anel, mas } \\
\text { entregar para gente numa caixinha linda demais }\end{array}$ \\
\hline 6 & $\begin{array}{l}\text { Estava com meu marido e minha filha. Ficamos ficamos bastante preocupados, porque } \\
\text { tudo que tínhamos levado, carteira, dinheiro, documentos, estava tudo dentro da mochila }\end{array}$ \\
\hline 7 & $\begin{array}{l}\text { No momento estava apenas eu e meu namorado. No momento ficamos meio chateados, } \\
\text { mas depois achavamos legal a atitude dele ter aceitado que foi grosso e pedir desculpas, } \\
\text { mesmo que nós que tenhamos cometido esse comportamento inadequado }\end{array}$ \\
\hline 8 & $\begin{array}{l}\text { Estava sozinha, mas acabei conversando com outras pessoas que também tiveram o fast } \\
\text { pass trocado e ficamos todos muito agradecidos }\end{array}$ \\
\hline 9 & $\begin{array}{l}\text { Com minha família, meus pais e dois irmãos que já tinham ido. Ficamos muito felizes e } \\
\text { agradecemos bastante pelo tratamento }\end{array}$ \\
\hline 10 & Estava com minha mãe e meu pai. Ficamos todos muito felizes e gratos \\
\hline 11 & $\begin{array}{l}\text { Estava com minha família, mulher e duas filhas. Foi uma emoção só, ficamos super } \\
\text { felizes e agradecemos imensamente, salvou o aniversário da minha filha }\end{array}$ \\
\hline 12 & $\begin{array}{l}\text { Estava com minha família e com essa outra família. Ficamos dando graças a Deus da } \\
\text { funcionária ter conseguido resolver a situação e feito ela parar de chorar. Foi muito legal } \\
\text { o que ela fez e realmente deu certo }\end{array}$ \\
\hline 13 & $\begin{array}{l}\text { Estava só eu e minha filha. Acabei nem comentando muito com ela, mas percebi que ela } \\
\text { estava bem triste. Tentei distrair indo em outros brinquedos }\end{array}$ \\
\hline 14 & $\begin{array}{l}\text { Estava só eu e minhas duas primas. Nós ficamos chocados né, porque nunca } \\
\text { esperávamos que ela fosse dar um ingresso para voltarmos ao Magic Kingdom a hora que } \\
\text { quisessemos, e ainda deu uma pantufa para minha prima que guarda com o maior carinho } \\
\text { até hoje }\end{array}$ \\
\hline 15 & $\begin{array}{l}\text { Estava com a minha família, mãe, pai e minha irmã gêmea. Eles adoraram o tratamento } \\
\text { que a Disney deu a um ponto que era muito delicado para mim. }\end{array}$ \\
\hline 16 & $\begin{array}{l}\text { Com meus pais e minha irmã. Ficamos bem tristes no momento, mas quando recebemos } \\
\text { os fast passes ficamos felizes de poder aproveitar outros brinquedos que ainda não } \\
\text { havíamos conhecido }\end{array}$ \\
\hline 17 & $\begin{array}{l}\text { Com meu tio e primo mais novo. Meu primo estava deslumbrado com o que estava } \\
\text { acontecendo, então eu e meu tio ficamos muito felizes por ver ele assim. }\end{array}$ \\
\hline
\end{tabular}

\begin{tabular}{|c|l|}
\hline & $\begin{array}{l}\text { 7. O que você e as pessoas que estavam te acompanhando falaram depois do } \\
\text { incidente? (atitude) }\end{array}$ \\
\hline 1 & $\begin{array}{l}\text { Todo mundo falou que a Disney é extremamente atenciosa e fui super cuidadosa, e } \\
\text { também que dei muita sorte porque ninguém agiu de má fé. Porque passam muitas } \\
\text { pessoas lá e ninguém pegou o celular. E não só isso, os próprios funcionários da Disney } \\
\text { não pegaram o celular. Porque acontece muito isso dentro de estabelecimentos né, de } \\
\text { funcionário pegar? Existem milhares de funcionários lá, e nenhum deles pegou, foram } \\
\text { superatenciosos, ligaram para avisar e ainda mandaram para o hotel, sem cobrar nada. } \\
\text { Eles mostraram real que se importaram com minha perda e muito estabelecimento tá nem } \\
\text { aí, até porque essa é a regra né. Até mesmo regra deles, que eles não se responsabilizam, } \\
\text { mas mesmo assim eles deram total atenção }\end{array}$ \\
\hline 2 & $\begin{array}{l}\text { A gente comentou muito sobre o fato dele realmente ter ido procurar e quando não } \\
\text { achou, ele buscou outra alternativa ainda que foi oferecer esse cupom. E foi tudo bem } \\
\text { rápido e ele foi muito fofo. }\end{array}$ \\
\hline 3 & $\begin{array}{l}\text { Comentamos que o atendimento da Disney é realmente único e percebe as pessoas de } \\
\text { verdade }\end{array}$ \\
\hline
\end{tabular}


Comentamos o fato dela ter sido super solícita e como os funcionários da Disney têm esse diferencial comparado a outros tipos de atendimento

\begin{tabular}{|c|c|}
\hline 5 & $\begin{array}{l}\text { Minha família e eu comentamos o fato de ser uma atitude realmente fora do comum. } \\
\text { Ficamos super felizes já de recuperar o anel, e eles foram ainda além de entregar numa } \\
\text { caixinha que guardamos de lembrança até hoje }\end{array}$ \\
\hline 6 & $\begin{array}{l}\text { Ficamos mais tranquilos de termos achado a mochila e comentamos sore o quão o } \\
\text { funcionário foi solícito de ter nos acompanhado o momento inteiro }\end{array}$ \\
\hline 7 & $\begin{array}{l}\text { A gente comentou com o grupo depois, o pessoal concordou que não deveríamos ter } \\
\text { ficado nos beijando e que ele estava correto em chamar nossa atenção, mas realmente } \\
\text { não precisava ter sido grosso e que foi muito legal ele ter enxergado isso }\end{array}$ \\
\hline 8 & Comentei com minha família depois e todos acharam a atitude da funcionária super justa \\
\hline 9 & $\begin{array}{l}\text { Comentamos que achamos muito legal e também de todas vezes que paravam pra me } \\
\text { perguntar se eu estava gostando. Pessoas desconhecidas me abordando para saber como } \\
\text { eu estava, e eu me senti muito especial com isso }\end{array}$ \\
\hline 10 & $\begin{array}{l}\text { A gente comentou que foi uma atitude super legal e que já havíamos ouvido falar sobre } \\
\text { os funcionários fazerem isso, mas a gente nunca acredita que vai ser com a gente né. Foi } \\
\text { sensacional }\end{array}$ \\
\hline 11 & $\begin{array}{l}\text { Ficamos muito emocionados e gratos pela atitude dessa funcionária. Minha mulher até } \\
\text { chorou de emoção. Até hoje a gente comenta sobre esse momento incrível, de como a } \\
\text { funcionária fez algo que mudou completamente nossa viagem e trouxe tanta felicidade }\end{array}$ \\
\hline 12 & $\begin{array}{l}\text { Ficamos aliviados e chocados com o fato da funcionária ter sido tão delicada e ter } \\
\text { conseguido conversar com uma criança de } 7 \text { anos de igual para igual }\end{array}$ \\
\hline 13 & $\begin{array}{l}\text { A gente acabou não comentando muito sobre o ocorrido, fingimos muito que não } \\
\text { aconteceu. Porque a Disney em si foi tão incrível, só esse incidente que foi tão chato, } \\
\text { mas não deixamos estragar a viagem }\end{array}$ \\
\hline 14 & $\begin{array}{l}\text { Nós cometamos com o resto da excursão e ficaram todos muito chocados também e } \\
\text { felizes pela gente. Todos sabiam o quanto minha prima queria essa foto. Comentamos } \\
\text { muito na volta sobre essa postura diferenciada dos funcionários da Disney que de fato } \\
\text { não vemos aqui pelo Brasil }\end{array}$ \\
\hline 15 & $\begin{array}{l}\text { Elogiamos muito a empresa Disney e principalmente a atenção e o cuidado do } \\
\text { funcionário. }\end{array}$ \\
\hline 16 & $\begin{array}{l}\text { A gente comentou que se isso tivesse acontecido em qualquer outro lugar, o máximo que } \\
\text { os funcionários fariam seria pedir desculpas. A Disney simplesmente é incrível, ofereceu } \\
\text { outros fast pass para conhecermos outros brinquedos }\end{array}$ \\
\hline 17 & $\begin{array}{l}\text { Ficamos felizes com o fato do funcionário te chamado ele. Como os atendentes de lá } \\
\text { buscam sempre fazer algo que surpreende a gente positivamente mesmo que a gente } \\
\text { tenha expectativas bem altas }\end{array}$ \\
\hline
\end{tabular}

\begin{tabular}{|c|l|}
\hline & 8. Quais circunstâncias você percebe que levaram para essa situação? (percepção) \\
\hline 1 & $\begin{array}{l}\text { Eu acabei me descuindando e perdi o celular na atração. Fui orientada pela funcionário a } \\
\text { ir ao achados e perdidos, onde dei as informações necessárias }\end{array}$ \\
\hline 2 & A perda da orelha durante a ride, ela acabou saindo \\
\hline 3 & O erro deu não ter percebido que entrei na fila errada \\
\hline 4 & De estarmos meio perdidos e estarmos falando alto de não ter o mapa em português \\
\hline 5 & A funcionária ter esbarrado e ter deixado o anel cair no ralo \\
\hline 6 & Falta de atenção do meu marido e não termos achado de primeira nos achados e perdidos \\
\hline 7 & O meu comportamento inadequado e a resposta grosseira do segurança \\
\hline 8 & A manutenção inesperada no brinquedo \\
\hline 9 & $\begin{array}{l}\text { Não sei dizer como ele percebeu, mas acredito que ele deve ter escutado algo que eu } \\
\text { falei ou meus pais perguntando se eu estava gostando. E ele me deu esse botão }\end{array}$ \\
\hline 10 & $\begin{array}{l}\text { Acho que foi o fato do funcionário estar realmente atento a sua volta, de ter percebido } \\
\text { que eu deixei o sorvete cair e fiquei chateada. Ele foi super atencioso e empático }\end{array}$ \\
\hline
\end{tabular}




\begin{tabular}{|c|l|}
11 & $\begin{array}{l}\text { A funcionária ter percebido que minha filha estava chorando e ter tido a atitude de se } \\
\text { preocupar em resolver o nosso problema. De ter ido além da função dela. }\end{array}$ \\
\hline 12 & $\begin{array}{l}\text { A menina estar chorando e a funcionária ter conseguido ter essa simpatia e ter } \\
\text { conversado com ela }\end{array}$ \\
\hline 13 & O fato do Pinóquio ser distante e a funcionária da fila grosseira \\
\hline 14 & Ela ter oferecido uma informação errada, mas ter feito de tudo para contornar a situação \\
\hline 15 & A minha falta de atenção e porque estava feliz de estar realizando um sonho \\
\hline 16 & A manutenção do brinquedo que queríamos ir \\
\hline 17 & $\begin{array}{l}\text { O funcionário ter feito algo além do esperado. Ele ter percebido uma criança no meio e } \\
\text { ter decidido fazer algo com ela }\end{array}$ \\
\hline
\end{tabular}

\begin{tabular}{|c|l|}
\hline & 9. Como foi sua interação com o atendente? (atitude) \\
\hline 1 & $\begin{array}{l}\text { Foi ótima, tanto na atração quanto nos achados e perdidos. Foram super atensiosos e } \\
\text { fofos. Me ouviram e trataram do caso como se fosse de um conhecido deles }\end{array}$ \\
\hline 2 & Excelente. Ele mostrou muita iniciativa e disposição para ajudar, foi atencioso e rápido \\
\hline 3 & $\begin{array}{l}\text { Foi muito boa, ele foi super atencioso e me parabenizou e estava sorrindo o tempo } \\
\text { inteiro }\end{array}$ \\
\hline 4 & $\begin{array}{l}\text { Foi muito boa, porque ela foi super gente boa, deu dicas, pediu desculpas pelo mapa. } \\
\text { Descobrimos que ela era carioca também. }\end{array}$ \\
\hline 5 & $\begin{array}{l}\text { Foi excelente. As duas funcionárias que ajudaram a gente foram super gentis e } \\
\text { extremamente solícitas }\end{array}$ \\
\hline 6 & Foi ótima. Ele foi extremamente solícito e atencioso \\
\hline 7 & $\begin{array}{l}\text { No início foi ruim, mas depois ele sorriu e fui super gentil. Ficamos até conversando um } \\
\text { pocuo depois }\end{array}$ \\
\hline 8 & Foi ótima, ela foi super gentil comigo \\
\hline 9 & $\begin{array}{l}\text { Na hora, eu fiquei bem impactada, falei pouco, mas agradeci bastante. Ele foi super } \\
\text { gentil }\end{array}$ \\
\hline 10 & $\begin{array}{l}\text { Ah, eu amei, Foi muito boa. Ele foi super educado, sorriu o tempo inteiro, aquele sorriso } \\
\text { que você sente vontade de rir junto, sabe? }\end{array}$ \\
\hline 11 & Foi incrível. Ela foi excelente, super educada, gentil. Não poderia ter sido melhor \\
\hline 12 & $\begin{array}{l}\text { Foi muito boa mesmo. Ela foi muito legal, gentil e delicada. Conseguiu contornar a } \\
\text { situação que nem mesmo os pais estavam preparados. Agradecemos muito }\end{array}$ \\
\hline 13 & $\begin{array}{l}\text { Foi péssima, tanto com o personagem que não queria nem chegar perto da gente quanto } \\
\text { da funcionária que foi extremamente grossa }\end{array}$ \\
\hline 14 & $\begin{array}{l}\text { Muito boa. Ela foi super gentil, pediu mil desculpas quando percebeu que tinha errado, } \\
\text { foi uma fofa }\end{array}$ \\
\hline 15 & $\begin{array}{l}\text { Muito boa. Ele me abordou de uma maneira gentil, teve empatia com meu problema, } \\
\text { mesmo que parecesse besteira. }\end{array}$ \\
\hline 16 & $\begin{array}{l}\text { Foi ótima. Apesar de estarmos chateados, ela foi super educada e gentil com a gente o } \\
\text { tempo inteiro }\end{array}$ \\
\hline 17 & $\begin{array}{l}\text { Excepcional. Ele foi um fofo e falava devagar para dar tempo de traduzirmos para o meu } \\
\text { primo }\end{array}$ \\
\hline
\end{tabular}

\begin{tabular}{|c|l|}
\hline & 10. O que você falou para o funcionário e o que ele falou para você? \\
\hline 1 & $\begin{array}{l}\text { Eu falei na atração que tinha perdido, se poderia entrar e ver se estava ali. A funcionária } \\
\text { me explicou que não dava, mas me orientou com o que eu deveria fazer e que eu deveria } \\
\text { ir aos achados e perdidos, para detalhar o máximo possível. Quando cheguei lá, expliquei } \\
\text { tudo e eles anotaram e agradeceram. }\end{array}$ \\
\hline 2 & $\begin{array}{l}\text { Eu expliquei que tinha perdido e que estava bem triste porque iria embora e aquela } \\
\text { orelha iria servir de lembrança do meu intercâmbio. Ele disse que não precisa me } \\
\text { preocupar que daria um jeito. Depois ele voltou, pedindo desculpas por não ter achado, } \\
\text { mas que eu poderia pegar qualquer outra orelha para guardar como memória da viagem }\end{array}$ \\
\hline
\end{tabular}


Ele deu parabéns por ter sido honesta e eu agradeci. Ele ofereceu depois o fast pass e eu e minha família ficamos muito felizes

\begin{tabular}{|c|c|}
\hline 4 & $\begin{array}{l}\text { perguntou se precisávamos do mapa em português, entregou para a gente e pediu } \\
\text { culpas por não ter mais ele, mas que eles já iriam repor. Perguntou se queríamos dicas } \\
\text { como fazer o percurso, porque havia escutado nossa conversa e deu várias dicas legais } \\
\text { a a gente }\end{array}$ \\
\hline 5 & $\begin{array}{l}\text { Quando o anel caiu, a funcionária pediu mil desculpas e nós dissemos que não havia } \\
\text { problema nenhum. Ela perguntou se poderíamos esperar alguns minutos que ela iria } \\
\text { tentar resolver. Ficamos conversando sobre a viagem, ela perguntou se estávamos } \\
\text { gostando enquanto tentavam tirar o anel. Quando finalmente tiraram, ela perguntou se } \\
\text { poderíamos buscar ele no Guest Relations quando fôssemos embora para ela limpar o } \\
\text { anel. Agradecemos bastante e dissemos nossos nomes para na hora de buscar deixarem } \\
\text { reservardo para a gente. No final do parque, fomos lá e a moça que entregou para a gente } \\
\text { foi super gentil também, nos desejou uma ótima viagem }\end{array}$ \\
\hline 6 & $\begin{array}{l}\text { plicamos a situação da mochila e que acreditávamos estar nos achados e perdidos. Ele } \\
\text { s acompanhou até lá e continuou super educado quando meu marido ficou mais } \\
\text { rvoso dizendo que deveria estar lá. Ele perguntou se havia muito tempo do ocorrido, e } \\
\text { semos que não. Ele disse que poderia ainda estar no mesmo lugar e nos levou até lá. }\end{array}$ \\
\hline 7 & $\begin{array}{l}\text { Ele cutucou a gente e falou que estávamos em um ambiente cheio de criança e que nossa } \\
\text { atitude não estava sendo nem um pouco adequada. Meu namorado pediu desculpas e } \\
\text { falou que realmente erramos, mas não tinha porque o segurança ter sido grosseiro com a } \\
\text { gente. Ele logo ficou meio sem graça, pediu desculpas pela maneira que agiu. Depois } \\
\text { perguntou se estávamos gostando da viagem, dissemos que sim e acabamos conversando } \\
\text { um pouco sobre a atração Soarin. Quando a fila andou, ele agradeceu a nossa } \\
\text { compreensão e desejou felicidade para nós }\end{array}$ \\
\hline 8 & $\begin{array}{l}\text { imo dia no parque e que tinha marcado o fast pass com } \\
\text { i super gentil, pediu desculpas pelo incidente e que poderia } \\
\text { tra atração ou para mesma num horário mais tarde quando o } \\
\text { ncionamento. Pedi para pegar o fast pass no horário mais } \\
\text { ção. Ela me entregou e eu agradeci }\end{array}$ \\
\hline 9 & $\begin{array}{l}\text { sse que era. Ai ele perguntou se eu estava } \\
\text { mim. Me deu um botão e agradeceu por }\end{array}$ \\
\hline 10 & $\begin{array}{l}\text { agradeci, mas disse que estava tudo bem e mostrei o } \\
\text { o. Ele disse que não precisava, e que tinha que manter a } \\
\text { eu aceitasse o presente. Agradeci bastante. Ele sorriu e }\end{array}$ \\
\hline 11 & $\begin{array}{l}\text { perguntou porque minha filha estava chorando e expliquei tudo para ela. Ela } \\
\text { guntou se poderíamos ir com ela até o Guest Relations e fomos, ela ficou o caminho } \\
\text { ciro chamando nossa filha de princesa e perguntando se estávamos gostando da } \\
\text { gem, qual tinha sido nossa atração favorita. Quando chegamos lá, ela pediu alguns } \\
\text { hutos e logo depois voltou dizendo que o Mickey tinha preparado um presente para } \\
\text { ha filha. Nos levou até a loja, pegou o vestido e sapato. Dissemos que não precisava, } \\
\text { s ela insistiu. Entregou para minha filha e ficamos esperando ela vestir. Quando } \\
\text { tou, ela disse que o Mickey ia ficar muito feliz de saber que ela tinha gostado do } \\
\text { sente e falou para aproveitarmos nosso jantar. }\end{array}$ \\
\hline 12 & $\begin{array}{l}\text { a pediu desculpas e disse que a menina não poderia entrar no brinquedo por causa da } \\
\text { tura. Quando ela começou a chorar, a funcionária se ajoelhou e ficou na mesma altura } \\
\text { la, pediu desculpas e disse que ela ainda era muito pequena para ir no brinquedo, mas } \\
\text { ee numa próxima vez ela iria na primeira fileira ainda e depois falou que a Branca de } \\
\text { eve tinha passado lá procurando ela, mas como não achou deixou um presente } \\
\text { tardado. E disse que gostaria de encontrá-la em breve pelo parque. O choro parou na } \\
\text { ra e ela quis mostrar pra todo mundo o presente que ganhou e ir procurar a Branca de } \\
\text { eve. Agradecemos bastante a ela e ela disse que não foi nada. }\end{array}$ \\
\hline
\end{tabular}


13 para a gente fast pass para outros dois brinquedos que tinham recém lançado e disse para aproveitrmos a viagem e conhecermos melhor outros brinquedos que também iriam agradar a gente. Agradecemos bastante.

A conversa toda fiquei traduzindo o que ele falava para meu primo e vice versa. Primeiro ele se aproximou da gente e perguntou se meu primo queria ajudar a apagar as luzes do parque. Meu primo disse todo feliz que queria muito. O funcionário pegou uma varinha de um quiosque que tinha do lado, e disse que meu primo deveria então levantar a varinha e falar Bibidi Bobodi Bu e contar até 3. Meu primo repetiu e quando chego no 3, todas as luzes desligaram por causa da parada. Ele ficou muito feliz. O funcionário agradeceu a ajuda do meu primo e disse para ele guardar a varinha e só usar quando fosse necessário.

\begin{tabular}{|l|l|}
\hline & 11. Teve algum contato físico? \\
\hline 1 & Não \\
\hline 2 & Não \\
\hline 3 & Não \\
\hline 4 & Não \\
\hline 5 & Não \\
\hline 6 & Não \\
\hline 7 & Sim, ele me cutucou \\
\hline 8 & Não \\
\hline 9 & Sim, ele colocou o botão em mim \\
\hline 10 & Não \\
\hline 11 & Não \\
\hline 12 & Sim, ela colocou a mão no ombro da criança \\
\hline 13 & Não, quem dera tivesse tido \\
\hline 14 & Não \\
\hline 15 & Não \\
\hline 16 & Não \\
\hline 17 & Não \\
\hline
\end{tabular}
distantes porque ele ficou isolado da gente, sem querer encostar. Ai ela virou e simplesmente disse que ele não era obrigado a nada. Fiquei chocada que nem consegui onder, só virei a cara e fui embora Ela ela já não estava mais no pavilhão d infelizmente iríamos embora no dia seguinte e nossos ingressos já haviam acabado. Ela ofereceu um outro ingresso para a gente e avisou que com ele poderíamos ir ainda hoje para o Magic Kingdom encontrar a gatinha em tais horários que não vou lembrar agora. prima

Eu estava chorando e o atendente perguntou o que aconteceu. Eu expliquei para ele o que tinha acontecido e que estava muito triste. Ele perguntou quanto eu gostava do Stitch e e falei que gostava muito. Ele me deu um pin do Stitch e disse que já voltava para eu mais e aproveitar o dia. Quando abri o presente, só conseguia agradecer.

Explicamos para a funcionária do Guest Relations que havíamos visto antes na programação e que agora o brinquedo estava em manutenção, sendo que não deveria e que não estavámos felizes com isso porque gostávamos muito daquele brinquedo. Ela pediu mil desculpas pelo imprevisto, que infelizmente não tinha o que fazer. Ofereceu

\section{Teve algum contato físico?}

Eu disse para o Pinóqui que minha filha era muito fã dele e que estavámos muito felizes de encontrá-lo e ele nem tchan. Não podia responder por causa da máscara, mas nem rolou um toque, abraço nem nada. Depois comentei com a funcionária, dizendo que 


\begin{tabular}{|c|c|}
\hline & 12. Você considera que o atendimento tenha sido personalizado? (percepção) \\
\hline 1 & $\begin{array}{l}\text { Assim, foi personalizado. Mas acho que é o padrão Disney mesmo de você tratar a pessoa } \\
\text { super bem }\end{array}$ \\
\hline 2 & $\begin{array}{l}\text { Sim, bastante. Ele poderia ter só pedido desculpa, mas ele pareceu ter tido empatia por eu } \\
\text { ter perdido }\end{array}$ \\
\hline 3 & Sim, porque eles não ficam oferecendo fast pass para todo mundo \\
\hline 4 & $\begin{array}{l}\text { Achei bastante personalizado, porque como falei ela deu várias dicas para a gente legais e } \\
\text { foi super gentil }\end{array}$ \\
\hline 5 & $\begin{array}{l}\text { O atendimento foi a definição de personalizado. Ela foi super gentil e solícita, fez de tudo } \\
\text { para pegar o anel. Foi além do esperado }\end{array}$ \\
\hline 6 & $\begin{array}{l}\text { Com certeza. Ele nos acompanhou durante todo processo e ficou brincando com minha } \\
\text { filha que não estava entendendo nada da situação porque ainda é muito pequena }\end{array}$ \\
\hline 7 & Acho que foi normal. O legal dele mesmo foi ele ter pedido desculpas \\
\hline 8 & $\begin{array}{l}\text { Mesmo que ela estivesse oferecendo as duas opções para todos nós que tínhamos o fast } \\
\text { pass nesse horário, achei o atendimento bastante personalizado }\end{array}$ \\
\hline 9 & $\begin{array}{l}\text { Bastante. Ele percebeu que era minha primeira vez e que eu tinha dificuldade em falar } \\
\text { inglês, e foi falando bem devagar com muitos gestos }\end{array}$ \\
\hline 10 & $\begin{array}{l}\text { Com certeza. Porque ele foi super fofo e atencioso, insistiu para que eu aceitasse esse } \\
\text { presente que ele não pode dar para todo mundo né. }\end{array}$ \\
\hline 11 & $\begin{array}{l}\text { Nossa, foi extremamente personalizado. Ela poderia ter passado direto pela gente, mas ela } \\
\text { parou e perguntou o que havia de errado. Quando soube, nos levou para resolver e deu um } \\
\text { presente maginífico para minha filha. Ela tratou nosso caso como único }\end{array}$ \\
\hline 12 & $\begin{array}{l}\text { Bastante. Achei incrível o fato dela ter se ajoelhado e ficado na altura da criança, acho } \\
\text { que isso passou uma sensação ótima para a menininha. }\end{array}$ \\
\hline 13 & Zero foi. Eles foram super mal educados \\
\hline 14 & $\begin{array}{l}\text { Com certeza. Extremamente personalizado. Ela foi super atenciosa, entendeu nossa } \\
\text { situação, solícita e gentil. Ela foi incrível }\end{array}$ \\
\hline 15 & $\begin{array}{l}\text { Sim. Porque ele quis saber o que estava acontecendo e ele tratou do meu problema } \\
\text { específico, que era o Stitch }\end{array}$ \\
\hline 16 & $\begin{array}{l}\text { Acho que sim. Ela pode ter feito isso com outras pessoas também, mas me senti única no } \\
\text { momento em que ela entendeu o qu estavámos sentindo e pareceu de fato se importar }\end{array}$ \\
\hline 17 & $\begin{array}{l}\text { Nossa, sim! O funcionário foi até a gente, foi gentil e único. Deixou que meu primo } \\
\text { fizesse algo que para ele será algo inesquecível. A disposição do funcionário em tornar } \\
\text { algo simples em incrível, fez toda a diferença }\end{array}$ \\
\hline
\end{tabular}

\begin{tabular}{|c|c|}
\hline & $\begin{array}{l}\text { 12.0 que ocorreu para a experiência ter sido positiva ou negativa? (atitude) } \\
\text { 13. O que ocorreu para a experiência ter sido positiva ou negativa? (atitude) }\end{array}$ \\
\hline 1 & O fato deles terem sido super atenciosos e terem achado o celular \\
\hline 2 & $\begin{array}{l}\text { Ele ter ido além, porque buscou outra alternativa que não fosse apenas eu ficar sem a } \\
\text { orelha }\end{array}$ \\
\hline 3 & $\begin{array}{l}\text { Foi positiva porque o funcionário se atentou ao fato do que eu estava fazendo, ele poderia } \\
\text { nem ter percebido ou escolhido não tomar uma atitude sobre o que eu fiz }\end{array}$ \\
\hline 4 & Ela ter tido a atitude de ir lá buscar um mapa, entregar para gente e oferecer várias dicas \\
\hline 5 & Ela ter conseguido tirar o anel de lá e nos ter oferecido numa caixinha linda depois \\
\hline 6 & O funcionário ter tranquilizado a gente e ter ficado brincando com minha filha \\
\hline 7 & $\begin{array}{l}\text { A resposta grosseira inicial dele e depois ele ter sido super gentil e acabamos } \\
\text { conversando mais }\end{array}$ \\
\hline 8 & Ter essa atenção especial da funcionária, que perguntou qual era minha preferência \\
\hline 9 & $\begin{array}{l}\text { Então, ela foi bem positiva porque foi um momento único, bem mágico, de estar em um } \\
\text { lugar incrível e ainda receber esse atendimento, esse carinho especial dos funcionários } \\
\text { que me abordavam }\end{array}$ \\
\hline
\end{tabular}


10 Acho que foi todo esse atendimento dele, dele ter oferecido o sorvete e ter entendido que eu não derrubei de propósito.

11 Foi extremamente positiva por causa desse atendimento personalizado. Da funcionária ter sido solícita e de ter realmente se preocupado com minha filha.

12 O jeito que a funcionária conseguiu reverter a situação, explicou e ainda fez a criança parar de chorar.

\begin{tabular}{|c|l|}
\hline 13 & $\begin{array}{l}\text { A experiência foi negativa porque o personagem não quis nem chegar perto da minha } \\
\text { filha que estava claramente super feliz de encontrar com ele. E depois ficou pior ainda } \\
\text { quando a funcionária foi grossa com a gente }\end{array}$ \\
\hline 14 & $\begin{array}{l}\text { A funcionária tornou a experiência positiva. O que ela fez de ter entendido nossa situação } \\
\text { fez com que minha prima realizasse um sonho }\end{array}$ \\
\hline 15 & Ele ter percebido que eu estava chorando e ter resolvido fazer algo sobre \\
\hline 16 & $\begin{array}{l}\text { A funcionária ter sido empática com nossa situação e ter oferecido algo para diminuir } \\
\text { nossa tristeza }\end{array}$ \\
\hline 17 & $\begin{array}{l}\text { A gentileza e percepção do funcionário. Ele foi tão fofo de ter ido até a gente para } \\
\text { realizar algo incrível. }\end{array}$ \\
\hline
\end{tabular}

\begin{tabular}{|c|c|}
\hline & 14. O que você percebeu que levou o funcionário te atender? (percepção) \\
\hline 1 & $\begin{array}{l}\text { Acho que tem a ver com a cultura da Disney, de atender todos do melhor jeito possível e } \\
\text { fazer o possível para termos a melhor experiência }\end{array}$ \\
\hline 2 & Ele percebeu que eu estava triste e não queria que eu ficasse daquele jeito \\
\hline 3 & $\begin{array}{l}\text { Olha, não sei. Mas acredito que os funcionários são treinados para perceberem esses } \\
\text { momentos }\end{array}$ \\
\hline 4 & $\begin{array}{l}\text { Acho que por ela ter ouvido a gente conversar, e por ter empatia se colocou em nosso } \\
\text { lugar para ajudar a gente }\end{array}$ \\
\hline 5 & Acredito que eles são treinados para isso mesmo, para ir além das nossas expectativas \\
\hline 6 & $\begin{array}{l}\text { Acredito que pelo treinamento deles mesmo. Sei que a Disney preza muito por isso e que } \\
\text { a equipe seja muito bem preparada, sempre tratanto todo mundo muito bem }\end{array}$ \\
\hline 7 & $\begin{array}{l}\text { Acredito que porque os funcionários tentam manter essa imagem de perfeição, ainda mais } \\
\text { para crianças e a gente estava meio que estragando isso }\end{array}$ \\
\hline 8 & O fato dos cast members se importarem com a satisfação do cliente \\
\hline 9 & $\begin{array}{l}\text { Acho que foi o funcionário ter percebido que era minha primeira vez e o outros que } \\
\text { perceberam por causa do botão }\end{array}$ \\
\hline 10 & $\begin{array}{l}\text { Eles são treinados para serem assim né? De perceberem o que acontece a volta deles, de } \\
\text { serem generosos e felizes. }\end{array}$ \\
\hline 11 & A empatia da funcionária com toda certeza, sua generosidade e educação \\
\hline 12 & $\begin{array}{l}\text { Acho que por ela ser empática e não querer ninguém triste no turno dela. Para eles isso } \\
\text { parece muito importante }\end{array}$ \\
\hline 13 & $\begin{array}{l}\text { Olha, eu realmente não sei. Porque todos os outros funcionários foram mega gentis com a } \\
\text { gente. Eu acredito que eles deviam estar com muito mau humor para tratar a gente } \\
\text { daquele jeito }\end{array}$ \\
\hline 14 & A empatia dela. Parecia que ela estava tratando minha prima como família dela. \\
\hline 15 & Eu estar chorando copiosamente. \\
\hline 16 & Nós termos ido até lá e dizermos para ela que estávamos muito tristes \\
\hline 17 & $\begin{array}{l}\text { Acho que ele é treinado para perceber ações que ele pode fazer para deixar os clientes } \\
\text { mais felizes. Tem que estar muito atento }\end{array}$ \\
\hline
\end{tabular}

\begin{tabular}{|c|l|}
\hline & $\begin{array}{l}\text { 15. Você percebeu que o funcionário admitiu o erro e tentou resolver? Ele conseguiu } \\
\text { resolver? }\end{array}$ \\
\hline 1 & $\begin{array}{l}\text { Os funcionários lamentaram não poder deixar a gente entrar na atração para procurar o } \\
\text { celular, mas resolveram no final com nossa ficha do achados e perdidos }\end{array}$ \\
\hline
\end{tabular}


Ele tentou resolver e foi super rápido. Acabou não achando, mas ofereceu outra alternativa

Sim, foi um erro meu mesmo. Mas ao invés dele ter brigado comigo, ele foi super legal e agiu da melhor maneira possível

\begin{tabular}{|c|l|}
\hline 4 & $\begin{array}{l}\text { Ela pediu desculpas por não ter mais o mapa, e conseguiu resolver trazendo outros e deu } \\
\text { umas dicas que ajudaram a gente a organizar o percurso melhor pra galera }\end{array}$ \\
\hline 5 & $\begin{array}{l}\text { A funcionária pediu mil desculpas pelo erro de ter esbarrado, mas conseguiu resolver o } \\
\text { problema de maneira excelente. Conseguimos o anel e ainda veio numa caixinha super } \\
\text { arrumadinha }\end{array}$ \\
\hline 6 & $\begin{array}{l}\text { Ele admitiu que realmente deveria estar no achados e perdidos, mas que por não ter } \\
\text { passado muito tempo do ocorrido, que ainda poderia estar lá. E ele conseguiu resolver } \\
\text { tudo. }\end{array}$ \\
\hline 7 & $\begin{array}{l}\text { Ele admitiu o fato de ter sido grosso e pediu desculpas. Acabou resolvendo o problema } \\
\text { que eu e meu namorado evitamos o resto da viagem esse comportamento }\end{array}$ \\
\hline 8 & $\begin{array}{l}\text { A funcionária admitiu o erro do brinquedo estar com problemas e que meu fast pass } \\
\text { deveria ter sido utilizado. Mas ela conseguiu resolver, me oferecendo outras duas opções, } \\
\text { de poder usar em outra atração ou na mesma mais tarde }\end{array}$ \\
\hline 9 & Não foi bem um problema, mas foi uma atitude que ele que foi além do que imaginava \\
\hline 10 & $\begin{array}{l}\text { Não foi erro dele. Mas ele percebeu esse problema e resolveu, ele foi super generoso e } \\
\text { legal }\end{array}$ \\
\hline 11 & $\begin{array}{l}\text { O erro não foi especificamente dela, mas quando ela soube o que aconteceu fez de tudo } \\
\text { para resolver. Foi super solícita e atenciosa conosco. }\end{array}$ \\
\hline 12 & $\begin{array}{l}\text { Com certeza. Ela contornou a situação, explicou de maneira extremamente educada e } \\
\text { ainda deu um presente para que ela não chorasse. Foi um alívio enorme }\end{array}$ \\
\hline 13 & Não, ninguém tentou resolver nada. Ficamos mega chateadas \\
\hline 14 & $\begin{array}{l}\text { Sim. Ela havia oferecido uma informação errada, e conseguiu resolver oferecendo os } \\
\text { ingressos para que realizássemos um sonho. Ela ter sido empática e solícita que tornou } \\
\text { tudo incrível }\end{array}$ \\
\hline 15 & Erro não foi dele, mas ele fez minha experiência ser muito melhor \\
\hline 16 & $\begin{array}{l}\text { Adimitiu o erro e pediu desulpas pelo imprevisto. Ela não conseguiu resolver o fato de } \\
\text { estar em manutenção, mas ofereceu um "prêmio de consolação" que foi excelente } \\
\text { também }\end{array}$ \\
\hline 17 & Não teve erro, mas foi incrível a atitude desse funcionário \\
\hline
\end{tabular}

\begin{tabular}{|c|l|}
\hline & 16. O que você considera como um bom atendimento? (papel funcionário) \\
\hline 1 & Acho que dar atenção, fazer o cliente se sentir especial, tipo único \\
\hline 2 & $\begin{array}{l}\text { Para começar com educação, gentileza. Que resolva meu problema, entenda meu lado e } \\
\text { busque realmente resolver o que aconteceu, que me dê a melhor experiência possível }\end{array}$ \\
\hline 3 & Tem que estar atento aos clientes sempre \\
\hline 4 & Cortesia, atenção, eficiência no atendimento \\
\hline 5 & $\begin{array}{l}\text { Acho que quando os funcionários entendem de fato o que você quer. Valorizam o que } \\
\text { você quer e tentam fazer }\end{array}$ \\
\hline 6 & Atenção e disposição dos funcionários \\
\hline 7 & Acho que a pessoa tem que saber ser gentil e entender as necessidades dos clientes \\
\hline 8 & Atenção especial direcionada \\
\hline 9 & $\begin{array}{l}\text { Atendimento que olha pro cliente de forma personalizada, especial, bem carinhosa. } \\
\text { Entenda que é importante que o cliente se sinta único, e que todos serviços sejam } \\
\text { pensadas pro público e que faça com que sintam vontade de voltar }\end{array}$ \\
\hline 10 & Empatia, generosidade e sorrisos. Acho muito importante estar sorrindo sempre \\
\hline 11 & $\begin{array}{l}\text { Tem que ser alguém atencioso, generoso, educado. Demonstrar se preocupar e tentar } \\
\text { entender, e fazer o melhor possível }\end{array}$ \\
\hline 12 & Ser bastante profissional, educado, gentil e escutar os clientes \\
\hline
\end{tabular}




\begin{tabular}{|c|l|}
13 & $\begin{array}{l}\text { Tem que ser gentil, saber conversar com os clientes, sorrir sempre que possível e } \\
\text { demonstrar educação o tempo inteiro }\end{array}$ \\
\hline 14 & O trio: educação, respeito e empatia \\
\hline 15 & O funcionário ter atenção, empatia e disposição para atender \\
\hline 16 & Considero quando há empatia, educação, respeito e gentileza por parte do funcionário \\
\hline 17 & $\begin{array}{l}\text { Acho que o bom é você ser educado e conseguir fazer o que te pedem. Mas para ir além, } \\
\text { tem que ser solícito e ter atenção o tempo inteiro aos clientes }\end{array}$ \\
\hline
\end{tabular}

\begin{tabular}{|c|c|}
\hline & $\begin{array}{l}\text { 17. Você acredita que a Disney é referência em atendimento ao cliente? Por que? } \\
\text { (papel funcionário) }\end{array}$ \\
\hline 1 & $\begin{array}{l}\text { Com certeza. Nunca fui mal atendida ou atendida mais ou menos. Eles fazem a } \\
\text { experiência de milhares de pessoas ser a melhor possível sempre, e o legal é ouvir e saber } \\
\text { de várias situações que acnteceram com outras pessoas que comprovam isso }\end{array}$ \\
\hline 2 & $\begin{array}{l}\text { Como eu trabalhei lá, eu entendo realmente como a gente é treinado e sou muito fã do } \\
\text { atendimento lá. Em todos os treinamentos, somos treinados a não simplesmente resolver } \\
\text { o problema do cliente, mas ir além do que eles precisam. Dar o nosso máximo. Por } \\
\text { exemplo, se alguém pediu informação para ir algum lugar, você pode levá-lo até lá. Na } \\
\text { Disney, sempre têm isso de ir além, superar as expecativas e supreender. Oferecer } \\
\text { felicidade até nas pequenas coisas do atendimento. Para mim, é uma pioneira desssa } \\
\text { filosofia de fazer mais do que você pode, não é só ser bom, é ser excelente. }\end{array}$ \\
\hline 3 & $\begin{array}{l}\text { Com certeza. Porque os funcionários estão sempre atentos e buscam atender às } \\
\text { necessidades dos clientes, que ás vezes nós mesmos nem percebemos }\end{array}$ \\
\hline 4 & $\begin{array}{l}\text { Foi excelente. Sempre que você fala com alguém que já foi, eles sempre tem uma história } \\
\text { legal de como os funcionários lá são diferenciados. Eles também estão sempre felizes, } \\
\text { sendo super educados, atendendo tudo mundo bem. }\end{array}$ \\
\hline 5 & $\begin{array}{l}\text { Acho que sim, ela é diferente de qualquer outro lugar. Já viajei para outros lugares, mas } \\
\text { não é que nem a Disney. É tudo uma magia que tem em torno que faz toda a diferença }\end{array}$ \\
\hline 6 & $\begin{array}{l}\text { Sim. Porque percebo a predisposição de toda a equipe para que o cliente esteja satisfeito } \\
\text { e tenha a melor experiência possível nos parques da Disney }\end{array}$ \\
\hline 7 & $\begin{array}{l}\text { Sim. Já li livros sobre e sempre comentam sobre o atendimento deles. Das duas vezes que } \\
\text { fui, sempre fui atendida de forma excelente, sempre foram muito gentis. Menos dessa } \\
\text { vez, mas no final o funcionário acabou sendo bastante gentil }\end{array}$ \\
\hline 8 & $\begin{array}{l}\text { Sim! Os funcionários demonstram realmente se importar com a satisfação dos clientes e } \\
\text { agem de acordo com isso }\end{array}$ \\
\hline 9 & $\begin{array}{l}\text { Sim, bastante. Pelas minhas experiências de estar lá, vejo que eles tem um atendimento } \\
\text { que é diferente de qualquer lugar que eu conheça. Eles sabem fazer isso bem, parece que } \\
\text { eles estão recebendo a gente na casa deles. É muito mágico mesmo }\end{array}$ \\
\hline 10 & $\begin{array}{l}\text { Com toda certeza. A Disney tem até uma faculdade para treinar os funcionários. Eles são } \\
\text { super certos com isso, Estão sempre sorrindo, bem vestidos, são extremamente educados } \\
\text { e gentis. }\end{array}$ \\
\hline 11 & $\begin{array}{l}\text { Acredito demais. Eles são um exemplo, todos os funcionários são sempre solícitos e } \\
\text { estão sempre sorrindo. E a funcionária que atendeu a gente demonstrou toda empatia e } \\
\text { generosidade }\end{array}$ \\
\hline 12 & $\begin{array}{l}\text { Acredito sim. Eles são incríveis, não só essa funcionária como todos. São extremamente } \\
\text { gentis, tem vários funcionários dispostos a te atender em todos os lugares, preparados } \\
\text { para te ajudar. }\end{array}$ \\
\hline 13 & $\begin{array}{l}\text { Então, eu acredito que sim, eles são super referência. Tem um treinamento incrível para } \\
\text { os funcionários, todos pareciam ser super bem treinados e preparados para atender a } \\
\text { gente da melhor maneira possível. Mas não dá para ser tudo perfeito, e acabam tendo } \\
\text { umas pessoas de má indole ou em dias ruins }\end{array}$ \\
\hline 14 & $\begin{array}{l}\text { Com certeza. A própria definição de bom atendimento. Todos os funcionários são super } \\
\text { bem treinados, educados, sempre sorrindo e extremamente solícitos e prontos para } \\
\text { atender a gente como se fôssemos da família deles }\end{array}$ \\
\hline
\end{tabular}


Com certeza. Porque a Disney se preocupa com a experiência do cliente, não só com a satisfação.

16 Sim. A gente consegue perceber o quanto eles são treinados para oferecer um serviço de excelência, com muita educação e empatia para todos os clientes.

17 Acredito sim. Eles estão sempre atentos e dispostos a fazer além do que esperamos deles. São educados, estão sorrindo o tempo inteiro, são super gentis e solicitos.

\begin{tabular}{|l|l|}
\hline & 18. Quantos anos você tem? \\
\hline 1 & 21 \\
\hline 2 & 20 \\
\hline 3 & 24 \\
\hline 4 & 22 \\
\hline 5 & 40 \\
\hline 6 & 33 \\
\hline 7 & 15 \\
\hline 8 & 25 \\
\hline 9 & 19 \\
\hline 10 & 17 \\
\hline 11 & 45 \\
\hline 12 & 22 \\
\hline 13 & 38 \\
\hline 14 & 25 \\
\hline 15 & 24 \\
\hline 16 & 16 \\
\hline 17 & 28 \\
\hline
\end{tabular}

\begin{tabular}{|c|l|}
\hline & 19. Qual sua ocupação? \\
\hline 1 & Estudante \\
\hline 2 & Estudante \\
\hline 3 & Estudante \\
\hline 4 & Estudante \\
\hline 5 & Gerente de Vendas \\
\hline 6 & Professora de Português \\
\hline 7 & Estudante \\
\hline 8 & Analista de Marketing \\
\hline 9 & Estudante \\
\hline 10 & Estudante \\
\hline 11 & Gerente de Marketing \\
\hline 12 & Analista de Trade \\
\hline 13 & Gerente de Loja \\
\hline 14 & Técnico de Informática \\
\hline 15 & Estudante \\
\hline 16 & Estudante \\
\hline 17 & Analista de Marketing \\
\hline
\end{tabular}

\section{Qual seu estado civil?}

$1 \quad$ Solteiro (a) 


\begin{tabular}{|c|l|}
\hline 2 & Solteiro (a) \\
\hline 3 & Solteiro (a) \\
\hline 4 & Solteiro (a) \\
\hline 5 & Casado (a) \\
\hline 6 & Casado (a) \\
\hline 7 & Solteiro (a) \\
\hline 8 & Solteiro (a) \\
\hline 9 & Solteiro (a) \\
\hline 10 & Solteiro (a) \\
\hline 11 & Casado (a) \\
\hline 12 & Solteiro (a) \\
\hline 13 & Divorciado (a) \\
\hline 14 & Solteiro (a) \\
\hline 15 & Solteiro (a) \\
\hline 16 & Solteiro (a) \\
\hline 17 & Solteiro (a) \\
\hline
\end{tabular}

